\title{
PALEOSEISMIC AND LIDAR INVESTIGATIONS \\ ALONG THE CATHEDRAL RAPIDS AND DOT "T" JOHNSON FAULTS, INTERIOR ALASKA
}

by

Rich D. Koehler and Rebecca-Ellen Farrell Woods

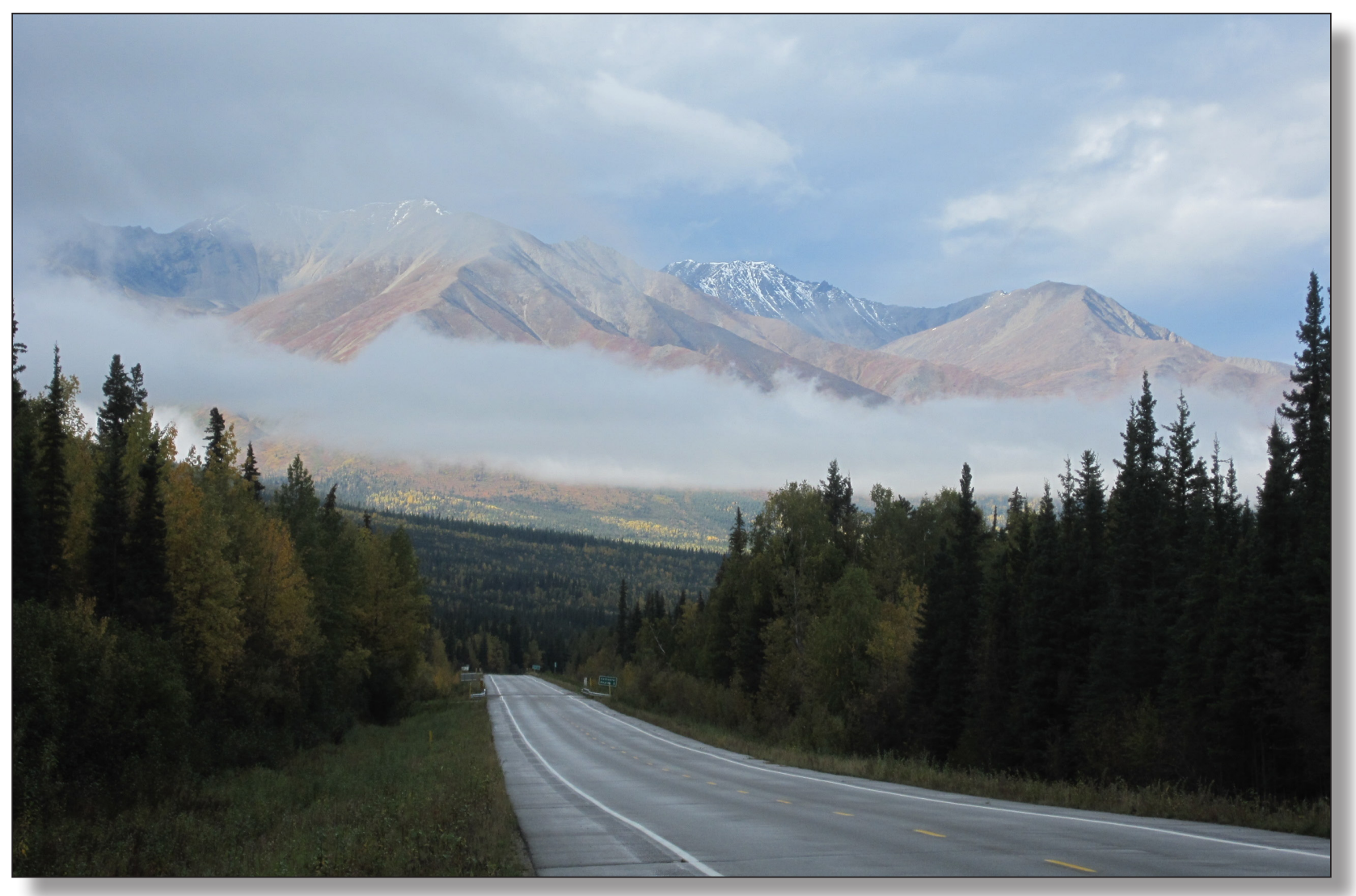

Mountain-scale triangular facets illuminated by morning light and obscured by fog along the northern flank of the Alaska Range and Cathedral Rapids fault in late September. Photo: Rich Koehler

\section{Published by}

STATE OF ALASKA

DEPARTMENT OF NATURAL RESOURCES

DIVISION OF GEOLOGICAL \& GEOPHYSICAL SURVEYS 


\section{Report of Investigations 2013-4}

\section{PALEOSEISMIC AND LIDAR INVESTIGATIONS ALONG THE CATHEDRAL RAPIDS AND DOT "T" JOHNSON FAULTS, INTERIOR ALASKA \\ by \\ Rich D. Koehler and Rebecca-Ellen Farrell Woods}

2013

This DGGS Report of Investigations is a final report of scientific research. It has received technical review and may be cited as an agency publication. 


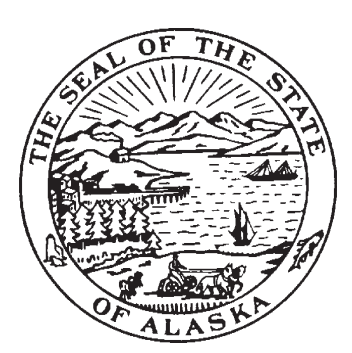

STATE OF ALASKA

Sean Parnell, Governor

DEPARTMENT OF NATURAL RESOURCES

Joe Balash, Commissioner

\section{DIVISION OF GEOLOGICAL \& GEOPHYSICAL SURVEYS \\ Steven Masterman, Acting State Geologist and Director}

Publications produced by the Division of Geological \& Geophysical Surveys (DGGS) are available for free download from the DGGS website (www.dggs.alaska.gov). Publications on hard-copy or digital media can be examined or purchased in the Fairbanks office:

\section{Alaska Division of Geological \& Geophysical Surveys 3354 College Rd., Fairbanks, Alaska 99709-3707 \\ Phone: (907) 451-5020 Fax (907) 451-5050 dggspubs@alaska.gov www.dggs.alaska.gov}

Alaska State Library

State Office Building, 8th Floor 333 Willoughby Avenue

Juneau, Alaska 99811-0571

Elmer E. Rasmuson Library University of Alaska Fairbanks Fairbanks, Alaska 99775-1005
Alaska Resource Library \& Information Services (ARLIS)

3150 C Street, Suite 100

Anchorage, Alaska 99503-3982

University of Alaska Anchorage Library 3211 Providence Drive Anchorage, Alaska 99508-4614 


\section{CONTENTS}

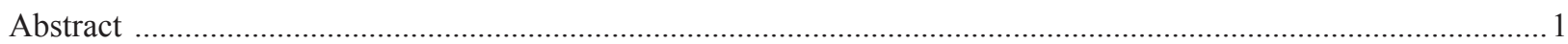

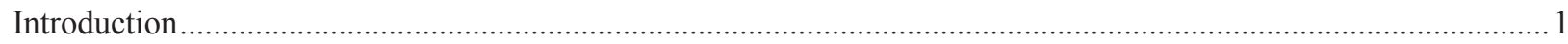

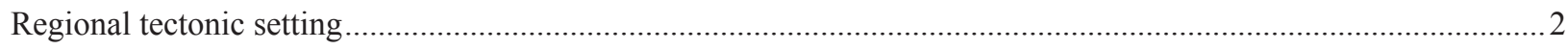

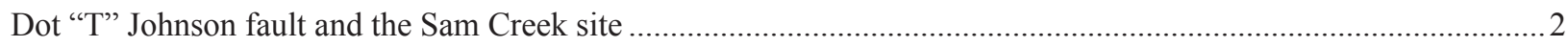

Derivative LiDAR maps of the Sam Creek site (.................................................................................................

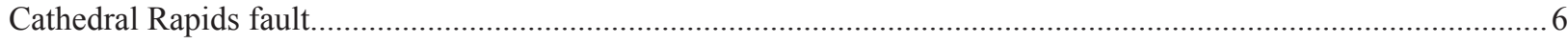

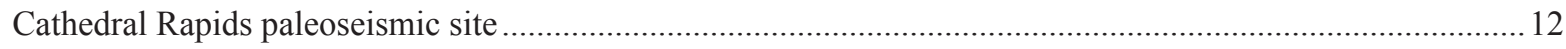

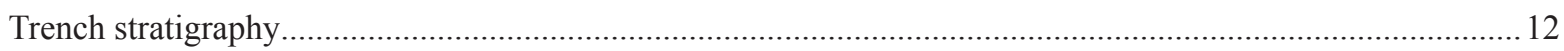

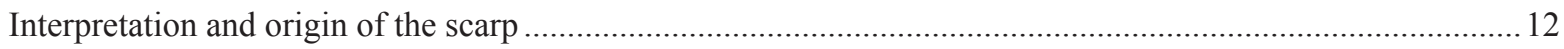

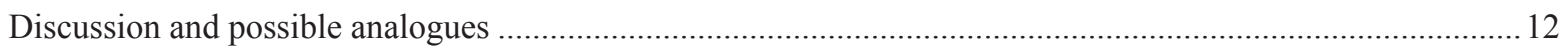

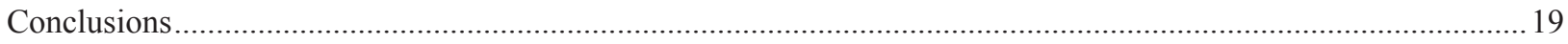

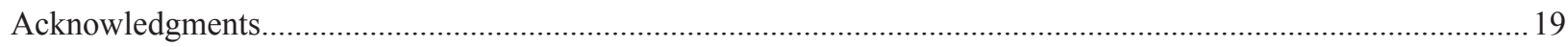

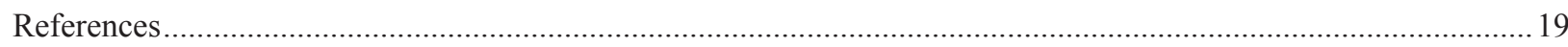

\section{FIGURES}

Figure 1. Maps showing location of study area and the distribution of faults in Alaska ......................................2

2. Geologic map of the Dot "T" Johnson fault area, and satellite image of the Tanana River floodplain

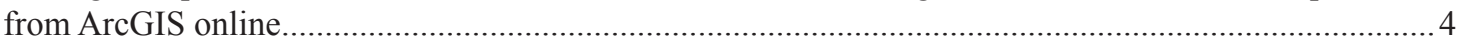

3. Topographic profiles of terrace and abandoned channel of Sam Creek and interpretation of the

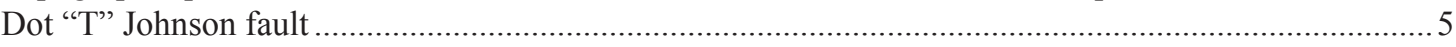

4. LiDAR derivative maps of the area between Sears Creek and Sam Creek along the Dot "T" Johnson

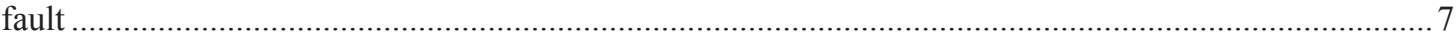

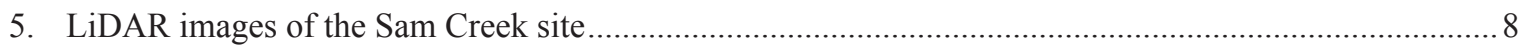

6. LiDAR derivative maps of the area between Sears Creek and Sam Creek along the Dot "T" Johnson

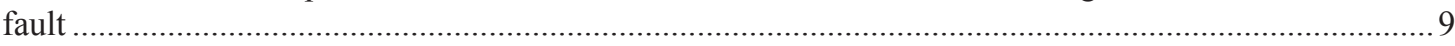

7. Surface roughness derivative map of the area between Sears Creek and Sam Creek along the

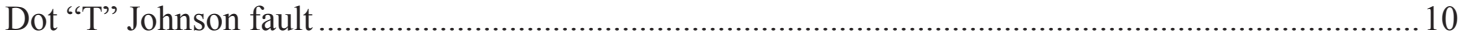

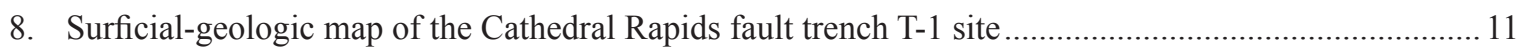

9. LiDAR image and aerial photograph of scarp along the Cathedral Rapids fault, showing location of

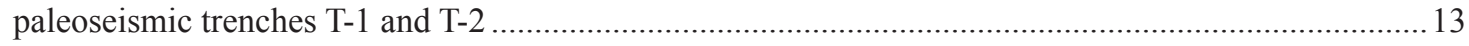

10. Stratigraphic log and photograph of the exposure of trench T-1 (east wall) along the Cathedral

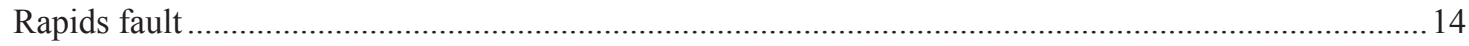

11. Stratigraphic log and photograph of trench T-1 (west wall) along the Cathedral Rapids fault ................15

12. Stratigraphic log of trench T-2 (east wall), showing similar stratigraphic relations at the toe of the scarp to those exposed in trench T-1

13. Exposure of the 1980 Algeria rupture showing blind thrust fault and associated folding; trench log from the Seattle fault showing folding of Holocene lake mud above a blind thrust fault; and photo showing 1999 Chi-Chi earthquake folding at the KuangFu middle school in Taiwan..

\section{TABLE}

Table 1. Radiocarbon data from the Cathedral Rapids trenches 



\title{
PALEOSEISMIC AND LIDAR INVESTIGATIONS ALONG THE CATHEDRAL RAPIDS AND DOT “T" JOHNSON FAULTS, INTERIOR ALASKA
}

\author{
by \\ Rich D. Koehler ${ }^{1}$ and Rebecca-Ellen Farrell Woods ${ }^{1,2}$
}

\begin{abstract}
The Dot "T" Johnson and Cathedral Rapids faults represent the eastern part of the Northern Foothills fold and thrust belt, and are geomorphically well expressed by triangular facets, anticlinal warps, and scarps in Quaternary deposits between Granite Mountain and Tok River. Previous paleoseismic trenching indicates that these faults have both generated at least one and possibly multiple Holocene earthquakes. We created various LiDAR-derived base maps along the Dot "T" Johnson fault to assess the relative utility of each product in assessing the location of tectonic features. Our results indicate that the most robust interpretations require combined observations from multiple products including hillshade, slope, intensity, and aspect maps. Interpretation of a new paleoseismic trench excavated across the Cathedral Rapids fault places a constraint on the timing of a folding event to after around $850 \mathrm{cal} \mathrm{yr} \mathrm{BP.} \mathrm{On} \mathrm{the} \mathrm{basis} \mathrm{of} \mathrm{folded}$ deposits and unconformable stratigraphic relations, we infer the existence of an active blind thrust splay of the Cathedral Rapids fault beneath the scarp.
\end{abstract}

\section{INTRODUCTION}

The Alaska Division of Geological \& Geophysical Surveys (DGGS) has conducted geologic field studies along the Alaska Highway corridor from Delta Junction, Alaska, to the Canada border (fig. 1), including identification and characterization of active faults. These investigations were performed to provide baseline geologic information for engineering design decisions related to the proposed Alaska-Canada natural gas pipeline and other developments in the corridor.

In 2011, DGGS acquired and processed high-resolution LiDAR data covering a 1-mi-wide corridor along the major transportation corridors in the state (Hubbard and others, 2011). LiDAR data provide a means to improve analyses of the landscape and facilitate efficient identification and characterization of geologic hazards in regions where other methods have been ineffective due to rugged topography, limited access, dense vegetation, and inadequate imagery. Several relatively simple techniques can be applied to LiDAR data in ArcMap to generate various base maps that are useful in identifying subtle topographic features (such as fault scarps) critical to characterizing geologic hazards including faults, landslides, permafrost, flooding, and other hazards (for example, Frankel and Dolan, 2007). These derivative base maps include bare-earth hillshade, intensity, slope, aspect, and surface roughness maps, among others. When combined with standard geologic and topographic maps and aerial imagery, these maps provide unparalleled insight into the geomorphology of an area.
Along the Alaska Highway corridor, a series of south-dipping imbricate thrust faults bound the northern flank of the Alaska Range (Bemis and others, 2012; Carver and others, 2010; 2008; Brogan and others, 1975), including the Dot "T" Johnson and Cathedral Rapids faults, among others (fig. 1). Previous paleoseismic trenching studies along these faults determined that the faults are active and the source of several Holocene earthquakes (Carver and others, 2010; 2008). To better characterize these faults, we generated derivative base maps from LiDAR data along the Dot "T" Johnson fault between Sears Creek and Sam Creek and performed a paleoseismic trench investigation across a $\sim 2.5$-m-high scarp along the Cathedral Rapids fault that was interpreted to be the extension of the fault in alluvium.

In this paper, we describe the utility of the LiDAR derivative base maps and present examples of the maps used in the investigation, focusing on the Sam Creek site. Additionally, we present the results of the trenching investigation along the Cathedral Rapids fault and discuss several lines of evidence that support a tectonic origin for the scarp. These data complement previous geologic mapping and other field efforts aimed at understanding the location and types of geologic hazards that could potentially impact pipeline alignment and design (Carver and others, 2010; 2008; Reger and others, 2012; 2011; 2008b; Hubbard and Reger, 2010).

${ }^{1}$ Alaska Division of Geological \& Geophysical Surveys, 3354 College Road, Fairbanks, Alaska 99709-3707; $\underline{\text { rich.koehler@alaska.gov }}^{2}$ ${ }^{2}$ Currently with Shannon \& Wilson, Inc., 2355 Hill Road, Fairbanks, Alaska 99709 


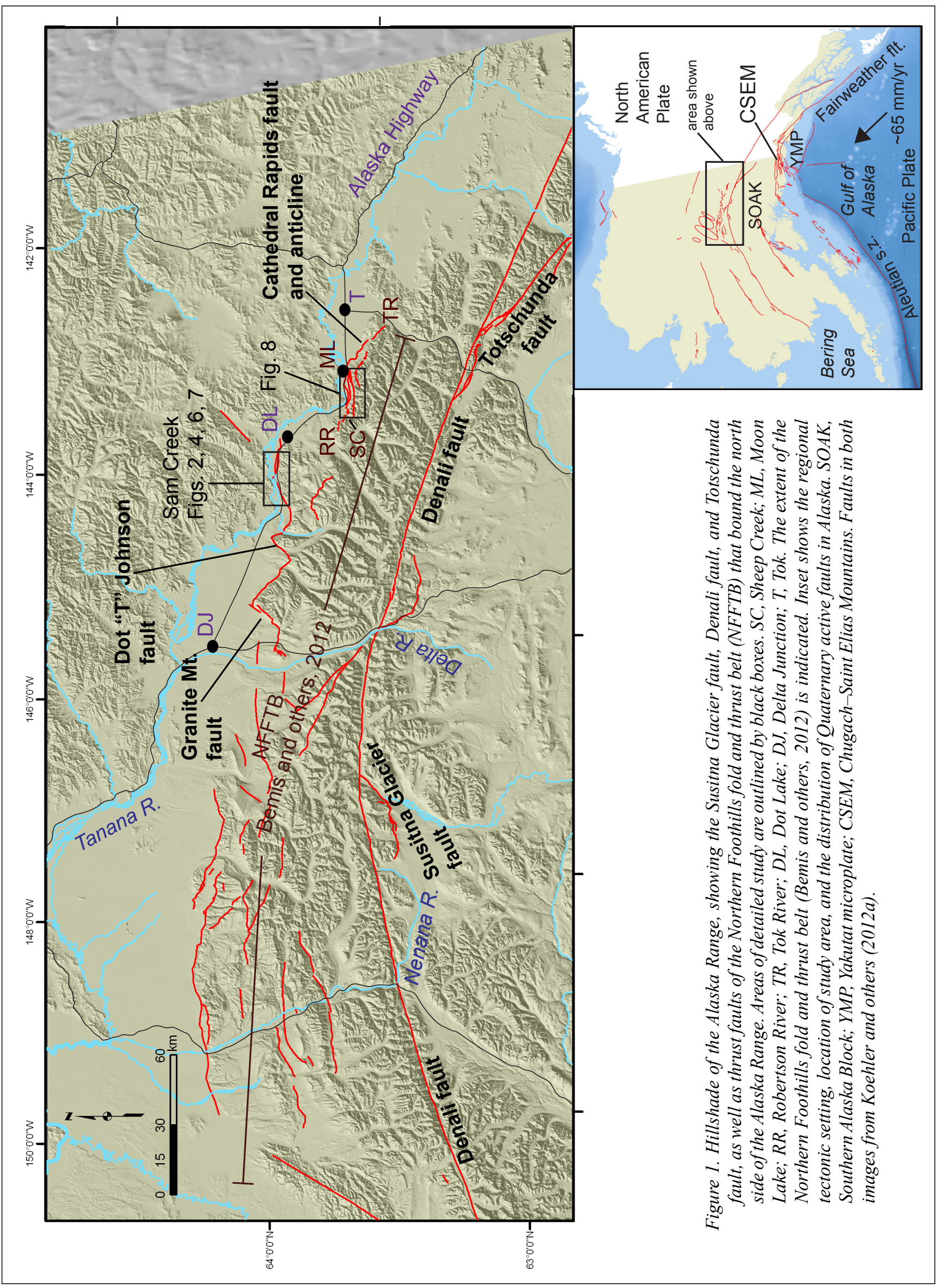




\section{REGIONAL TECTONIC SETTING}

Tectonic compression and shear deformation in interior Alaska are the result of oblique subduction of the Pacific plate and the relatively buoyant Yakutat microplate beneath the North American plate at a rate of $\sim 5.5 \mathrm{~cm} / \mathrm{yr}$ (Haeussler, 2008) (fig. 1). As part of this process, southern Alaska is deforming along the subduction margin by translation along the Fairweather fault and by fold-and-thrust-belt tectonics across the Chugach/St. Elias Mountains. Plate boundary forces not accommodated by deformation along the subduction front are transmitted northward and distributed across a broad zone extending more than $700 \mathrm{~km}$ into interior Alaska (Freymueller and others, 2008; Ruppert and others, 2008).

The Denali-Totschunda fault system (fig. 1) accommodates part of this deformation by dextral transpressive shear along the arcuate southern margin of the Alaska Range and is responsible for counterclockwise rotation of the block of crust between the Yakutat microplate and the Denali fault, known as the southern Alaska block (Haeussler, 2008; St. Amand, 1957). The Denali fault was the source of the $2002 \mathrm{M}_{\mathrm{w}}=7.9$ Denali fault earthquake, which ruptured $340 \mathrm{~km}$ along the Susitna Glacier thrust, Denali fault, and Totschunda fault (Haeussler and others, 2004; Eberhart-Phillips and others, 2003). Geodetic, InSar, geochronologic, and paleoseismic studies indicate a right-lateral slip rate of $\sim 9-14 \mathrm{~mm} / \mathrm{yr}$ (Meriaux and others, 2009; Biggs and others, 2007; Matmon and others, 2006; Fletcher, 2002).

Although the dominant sense of slip on the Denali fault is dextral, drainages of the Nenana and Delta rivers flow north across the crest of the central Alaska Range, indicating that they are antecedent to regional uplift. The Pliocene Nenana Gravel outcrops on both sides of the central Alaska Range and was deposited by northflowing rivers that were subsequently uplifted above local base level by thrust and/or reverse faulting (Bemis and Wallace, 2007; Ridgway and others, 2007; Thoms, 2000; Wahrhaftig and others, 1969). Thus, in addition to shear along the Denali fault, the presence of active thrust faults indicates that a north-directed component of compression is exerted across the Alaska Range and has played a significant role in the deformation and uplift of the range.

Quaternary thrust faulting, folding, and uplift is accommodated along the northern flank of the Alaska Range by the Northern Foothills Fold and Thrust Belt (NFFTB) (fig 1), a 50-km-wide, 500-km-long system of south-dipping imbricate thrust faults that accommodate $\sim 3 \mathrm{~mm} / \mathrm{yr}$ of dip-slip displacement (Bemis and others, 2012; Bemis, 2010, 2004; Bemis and Wallace, 2007; Geomatrix Consultants, 1997; Thorson, 1979). In the vicinity of the Nenana River, faults of the system deform the Nenana gravels into a series of anticlines (Bemis and Wallace, 2007; Péwé and others, 1966). East of the Delta River, the system includes the Donnelly Dome, Granite Mountain, Canteen, Dot "T" Johnson, and Cathedral Rapids faults. Specific details about individual faults of the NFFTB are described in Bemis and others (2012) and Carver and others (2010; 2008).

\section{DOT "T" JOHNSON FAULT AND THE SAM CREEK SITE}

The Dot " $T$ " Johnson fault is a south-dipping thrust fault extending $\sim 80 \mathrm{~km}$ between the Granite Mountain fault and Dot Lake (figs. 1 and 2A). The fault is connected to the Donnelly Dome fault across the left-normal oblique Granite Mountain fault and is interpreted by Bemis and others (2012) and Carver and others (2010) to be the eastern continuation of the Northern Foothills Fold and Thrust Belt. Paleoseismic trenching studies and geologic mapping along the Dot "T" Johnson fault at Sears Creek and Sam Creek (fig. 2A) indicate that the fault is active and has experienced at least one latest Pleistocene and one Holocene earthquake (Carver and others, 2010; 2008). At Sears Creek, Carver and others (2010) identified at least $3 \mathrm{~m}$ of dip-slip displacement of fluvial gravels along a $12^{\circ}-14^{\circ}$ south-dipping fault plane. The displacement event was estimated to have occurred more recently than 4,430-3,230 cal yr BP.

The Sam Creek site was initially investigated by Carver and others (2008) during reconnaissance geologic mapping related to DGGS's highway corridor geologic hazards investigations. They identified a 'mole track' scarp at the abandoned channel of Sam Creek about $0.4 \mathrm{~km}$ south of the Alaska Highway (fig. 2A). Several exploratory trenches across the scarp showed that the scarp cuts a loess-capped late Pleistocene Tanana River terrace. The terrace is interpreted to have been deposited during jökulhlaup floods generated from ice dam collapse along the Robertson River glacier or outburst floods from Lake Atna (Hubbard and Reger, 2010; Reger and others, 2008a,b; Schmoll, 1984). Carver and others (2008) measured topographic profiles perpendicular to the fault across the terrace and down the Sam Creek channel and showed that both have been warped and tilted to the south. They interpret that the south-facing scarp is the surface expression of a north-dipping back thrust on the south side of a large "pop-up" thrust wedge (fig. 3).

Hanging wall deformation along the north-dipping back thrust has caused progressive deformation of the outburst flood terrace deposit and abandonment of the Sam Creek channel (Carver and others, 2010). Paleoseismic trenches across the scarp at Sam Creek exposed south- and north-dipping secondary conjugate thrusts in the hanging wall above a primary thrust, which consists 

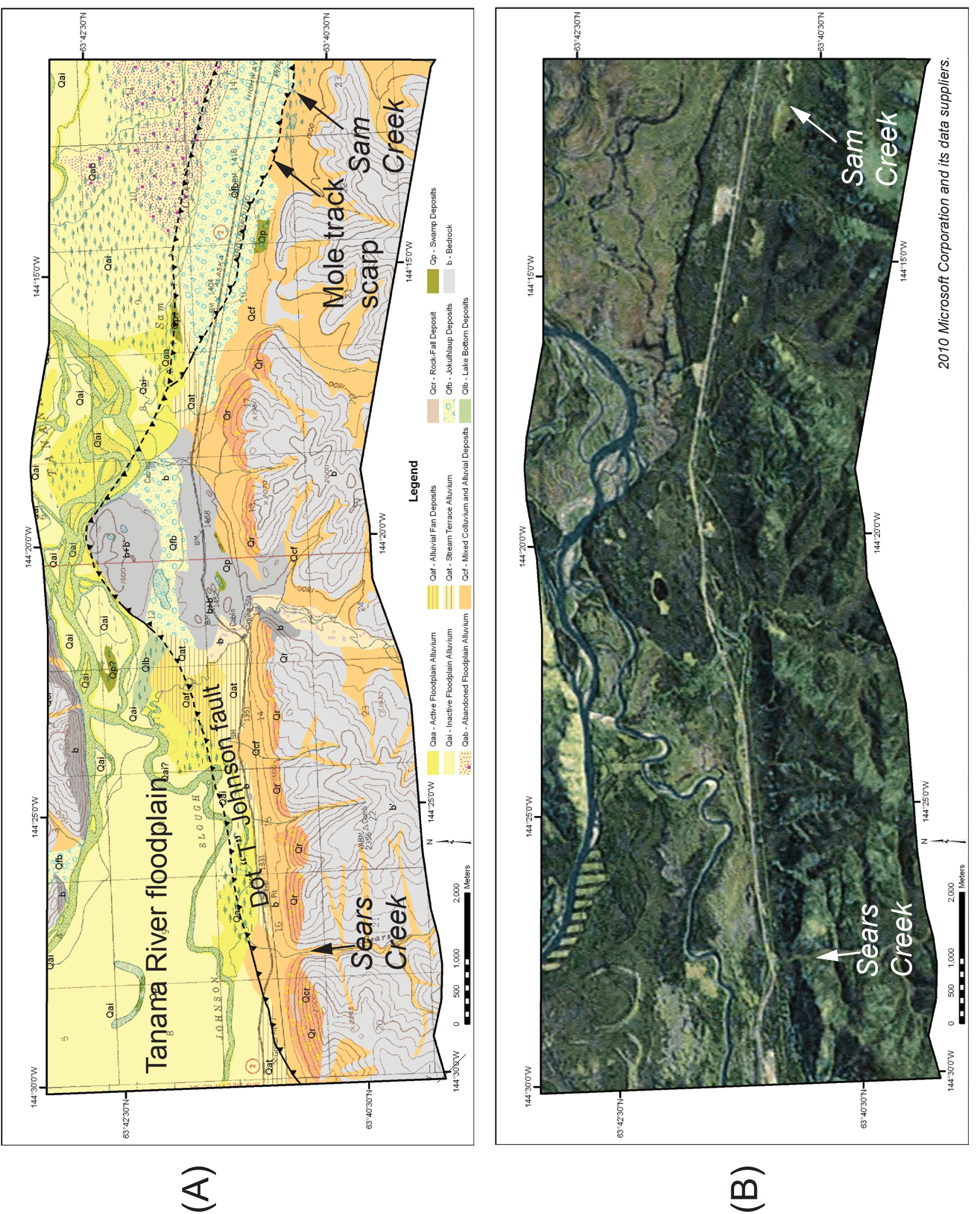

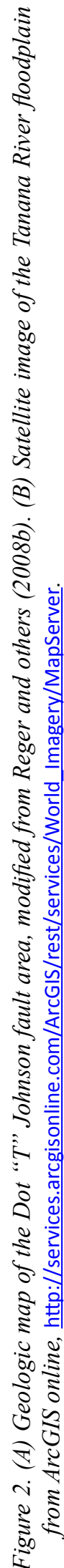




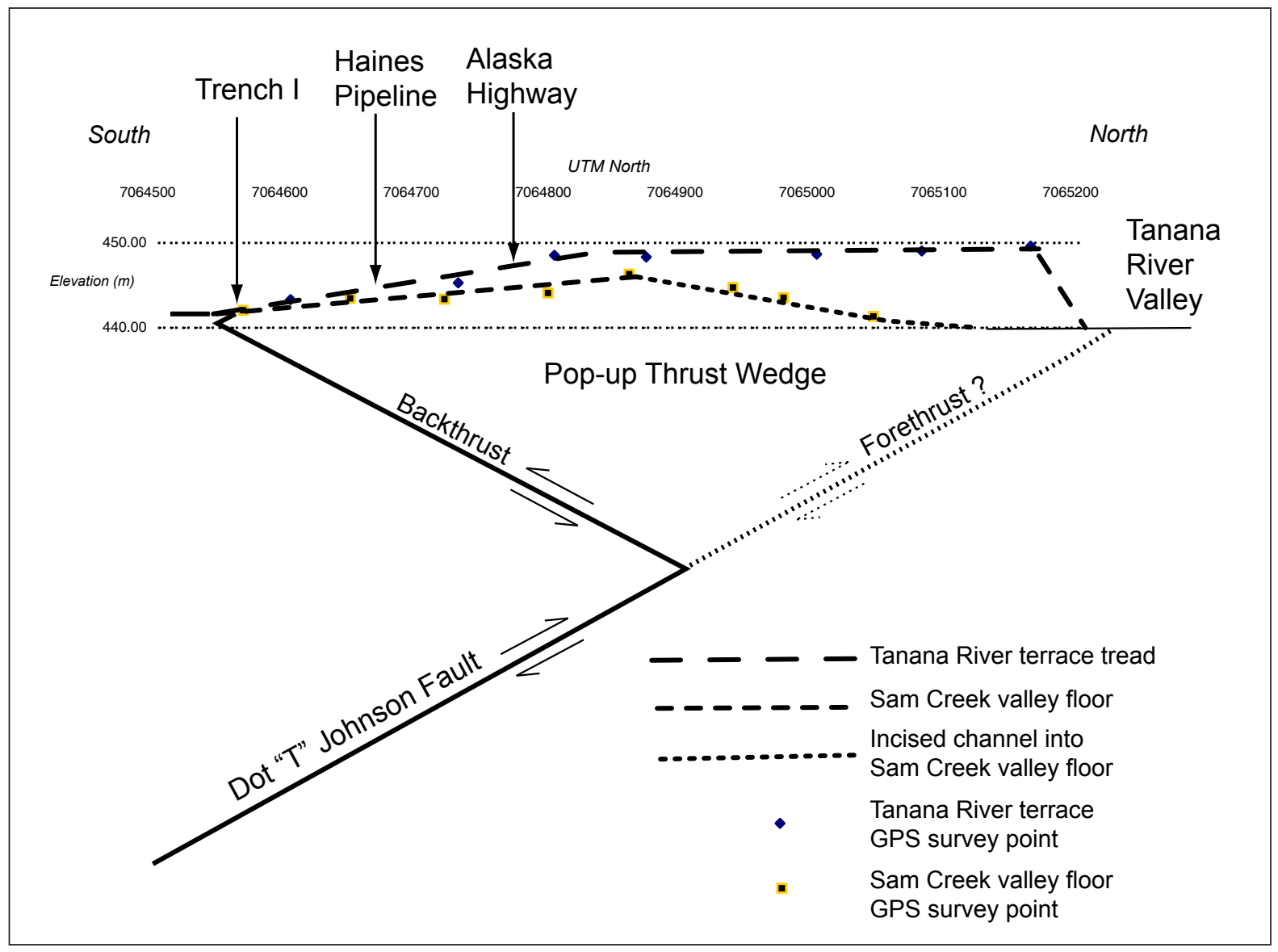

Figure 3. Topographic profiles of terrace and abandoned channel of Sam Creek, and interpretation of the Dot "T" Johnson fault. From Carver and others (2008).

of a low-angle zone of closely spaced micro-faults and shears (Carver and others, 2010; 2008). Radiocarbon analyses of charcoal in displaced deposits indicate the occurrence of an earthquake after 7,980-7,850 cal yr BP and several older latest Pleistocene events that predate $7,980-7,850$ cal yr BP and may be older than 11,350$11,210 \mathrm{cal}$ yr BP (Carver and others, 2010, 2008).

\section{DERIVATIVE LIDAR MAPS OF THE SAM CREEK SITE}

Available satellite and aerial imagery in Alaska lacks the necessary resolution to evaluate topographic features related to active tectonics and other geologic hazards (fig. 2B). Through the Geographic Information Network of Alaska (GINA) and the Statewide Digital Mapping Initiative (SDMI) programs at the University of Alaska Fairbanks, efforts are underway to acquire and make publicly available higher quality imagery. Although improved imagery is beneficial for geologic mapping and other studies, dense vegetation in some areas remains problematic in assessing tectonic features obscured beneath the forest canopy. LiDAR data alleviate this problem by sampling topography beneath the vegetative cover, illuminating the bare-earth topography, and providing a numerical elevation model that can be used for geomorphic analyses. Additionally, derivative base maps created in ArcMap using ArcTools can assist in the interpretation of neotectonics and Quaternary geology. A series of LiDAR derivative base maps were created to explore new ways of viewing the LiDAR data in the vicinity of Sam Creek and to evaluate methods used to assess geologic hazards throughout DGGS's highway corridor project.

High-resolution LiDAR imagery was acquired by DGGS in 2011 after completion of highway corridor surficial mapping and the Sam Creek paleoseismic investigations. Observations from surficial-geologic mapping indicated that the trace of the Dot " $T$ " Johnson fault was eroded along the margin of the Tanana River floodplain and that the fault cuts alluvial deposits and outburst flood deposits in the vicinity of Sears and Sam creeks, respectively (fig. 2A). Geologic contacts on the surficialgeologic map originally were mapped on 1:63,360-scale airphotos and topographic maps in the field. Once the LiDAR data were processed, the geologic contacts, 
including the location of fault traces, were updated based on hillshade images generated from the LiDAR, greatly improving the accuracy of the map (Reger and others, 2008b) (fig. 2A). Figure 4A shows a bare-earth model of the Sam Creek area and clearly shows the fault scarp of the Dot "T" Johnson fault. Areas of steep slopes and floodplain configuration can also easily be delineated. Elevation information contained in the raw point-cloud LiDAR data can be used in ArcMap to generate detailed contour maps and topographic profiles. The profiles and contour maps in figure 5 confirm the presence of the scarp at Sam Creek and show that it slopes to the south. Trenches across the scarp exposed north-dipping faults, from which Carver and others $(2010 ; 2008)$ inferred a 'pop-up' wedge mechanism of deformation (fig.3).

In areas with poor airphoto coverage, intensity maps derived from LiDAR point-cloud data can provide a valuable alternative (fig. 4B). Intensity maps can highlight subtle differences in Quaternary geologic units and their surface reflectance intensities, and in many cases, are better than available commercial aerial photographs. The ease of creating intensity images in ArcMap allows the user to generate high-resolution airphoto-like images rapidly, over broad regions. Slope maps that show the degree of slope angle in modifiable color bands are useful for detecting fault scarps in areas of low relief (fig. 6A). Scarps may be expressed as brightly colored lineaments due to their significantly steeper faces as compared to the surrounding topography. For example, a thin, light blue line clearly delineates the fault scarp at Sears Creek and Sam Creek (fig. 6A). Aspect maps can be created to illuminate specific slope aspects. In figure $6 \mathrm{~B}$, the color ramp shows a reversal of aspect across the outburst flood terrace deposit at Sam Creek, supporting the interpretation that the terrace is warped on the hanging wall above a north-dipping back thrust fault.

Estimates of surface roughness derived from LiDAR data can be used to quantitatively compare alluvial deposits and aid in correlation, mapping, and assessment of relative age. The basic premise is that alluvial surfaces become smoother with increasing age, and subtle differences in surface texture can be determined by averaging the surface slope over a set grid size. The surface roughness map in figure 7 was produced using the FocalStatistics tool in ArcMap and calculating the standard deviation of slope over a $3 \times 3 \mathrm{~m}$ grid. The method was modified from Frankel and Dolan (2007), who developed the technique to map alluvial fans of various ages in Death Valley, California. Our application of this method to the Sam Creek area indicates that inactive floodplain alluvium has different surface roughness characteristics in different areas, limiting its utility as a mapping tool. This may be related to differing amounts of peat growth on the surface and different flood erosion histories. The technique may be more useful in other areas of Alaska where deposits span a wider range of ages, such as in the Alaska Range where glacial moraines of late Wisconsin and penultimate ages are preserved.

Advancements in LiDAR technology provide unprecedented opportunities to interpret the surface of the earth rapidly and over broad regions. However, the LiDAR derivative products described above indicate that multiple methods should be applied to evaluate geologic hazards in a particular area. Slope and aspect maps can be manipulated to highlight particular features, therefore they are best utilized after some preliminary information is developed using bare earth models and field reconnaissance. For example, if a fault is determined to be east-west trending, aspect maps can be modified to show north- and south-facing slopes that may reveal small scarps that initially were not recognized. The techniques are particularly well suited to assess geologic hazards in areas characterized by diverse geologic environments, limited access, and rugged terrain. However, detailed field studies are necessary to confirm interpretations based on LiDAR-generated map products.

\section{CATHEDRAL RAPIDS FAULT}

The Cathedral Rapids fault extends $\sim 40 \mathrm{~km}$ between the Tok and Robertson river valleys and is interpreted to be the easternmost structure of the Northern Foothills Fold and Thrust Belt (Bemis and others, 2012; Carver and others, 2010) (figs. 1 and 8). The western part of the fault extends $21 \mathrm{~km}$ from Sheep Creek to Moon Lake and is characterized by well developed triangular facets and three roughly parallel, sinuous, south-dipping imbricate thrust splays (Carver and others, 2010) (fig. 8). The faults offset glacial deposits of the Illinoian to early Wisconsinan Delta glaciations and the late Wisconsinan Donnelly glaciation, as well as Holocene alluvial deposits (Reger and others, 2011; Carver and others, 2010). The eastern part of the fault extends $\sim 16 \mathrm{~km}$ from Moon Lake to the Tok River valley and is characterized by a large, sinuous growth anticline that extends across coalesced alluvial fans north of the range front (fig. 1). Progressively offset and tilted alluvial terraces, incised stream profiles that steepen across the anticline, and results of paleoseismic excavations are consistent with late Pleistocene and Holocene growth of the anticline (Carver and others, 2010). Based on a paleoseismic study of an exposure of a graben at the crest of the anticline, Carver and others (2010) documented colluvial fills interpreted to be related to extension in the hinge of the anticline during at least four latest Pleistocene earthquakes and a Holocene earthquake that occurred after $\sim 8 \mathrm{ka}$. An additional exposure in a trench across a small scarp at the base of the fold scarp indicated that the most recent earthquake occurred after AD 1650 (Carver and others, 2010). 

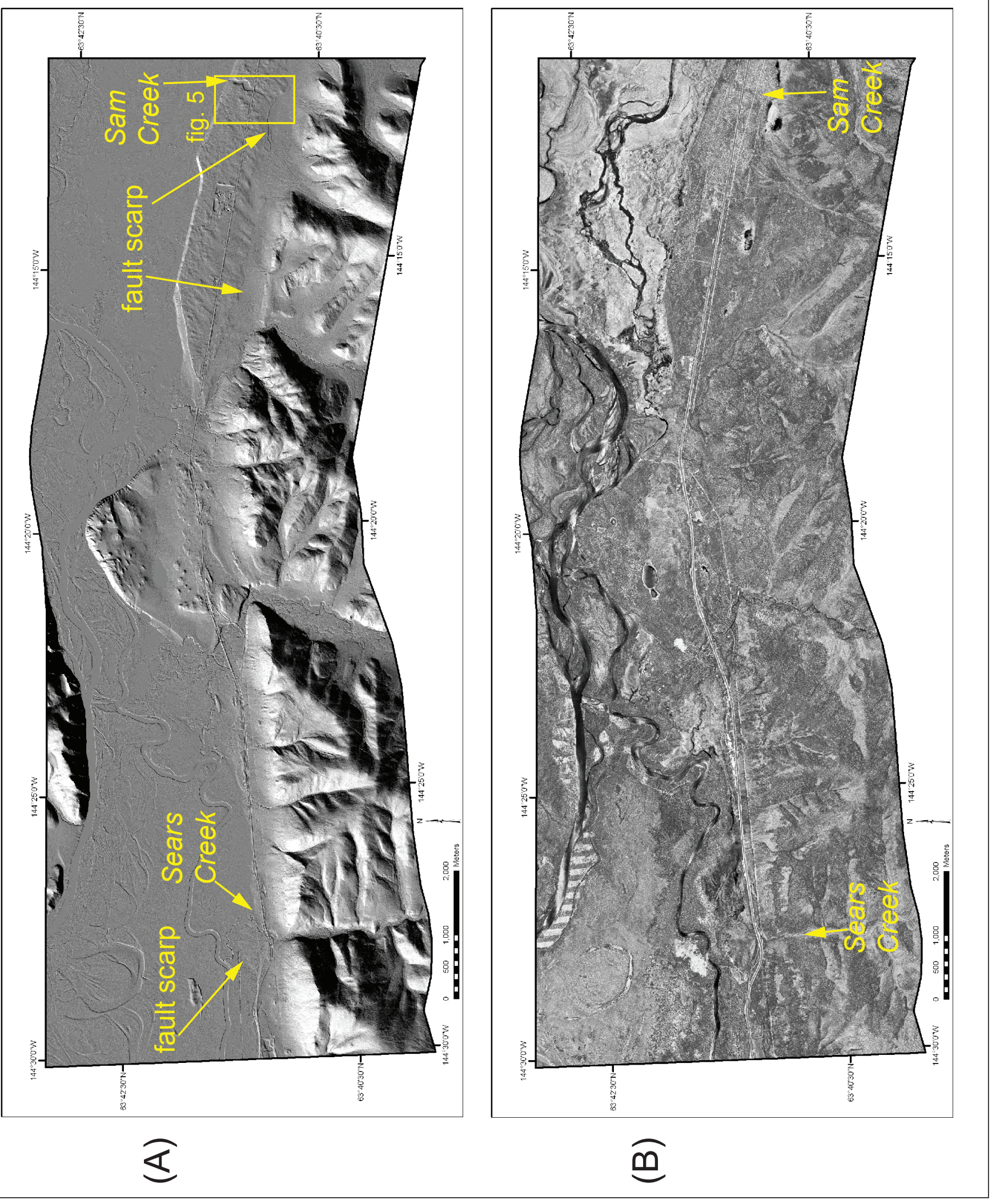

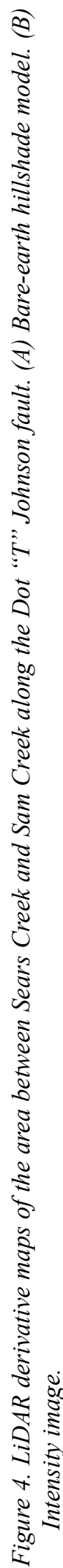




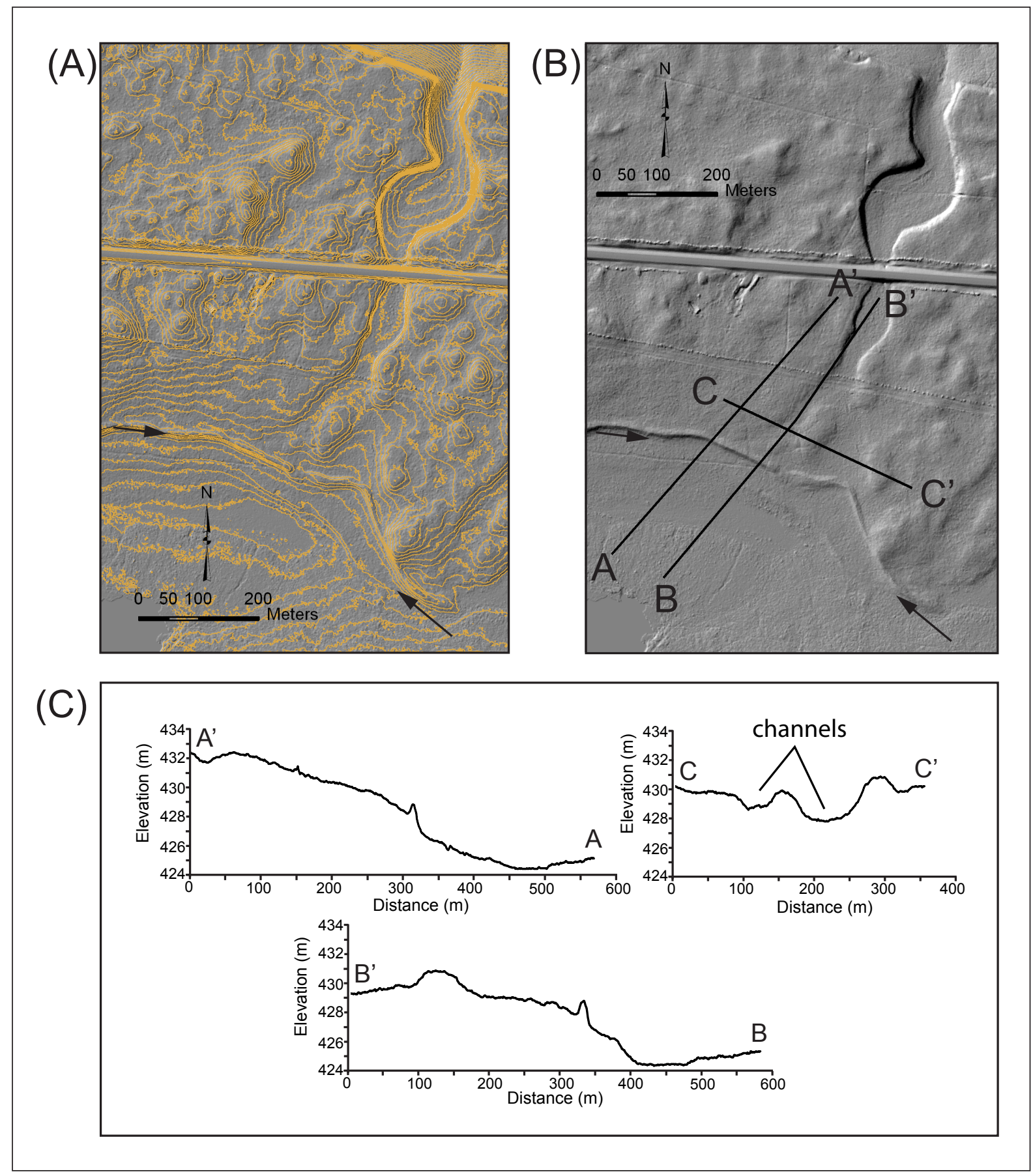

Figure 5. LiDAR images of the Sam Creek site. (A) $0.5 \mathrm{~m}$ contour map indicates the presence offault scarp shown between arrows. (B) Bare-earth hillshade, showing the abandoned channel of Sam Creek isolated by uplift on an inferred north-dipping backthrust. (C) Detailed topographic profiles generated from LiDAR data using ArcMap. See bare-earth image in (B) for locations of profiles. 


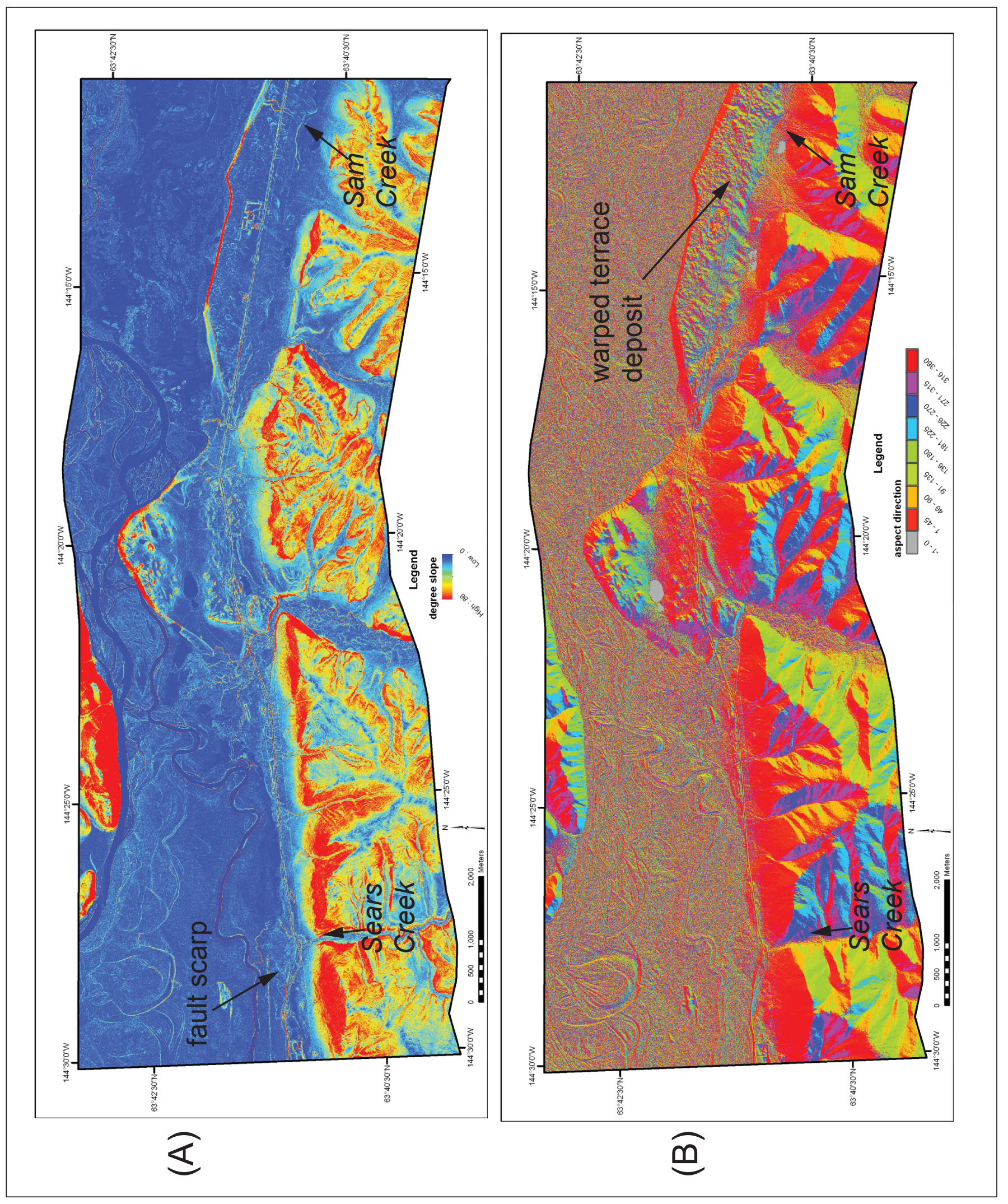

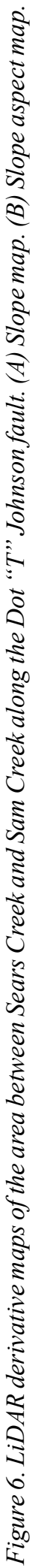




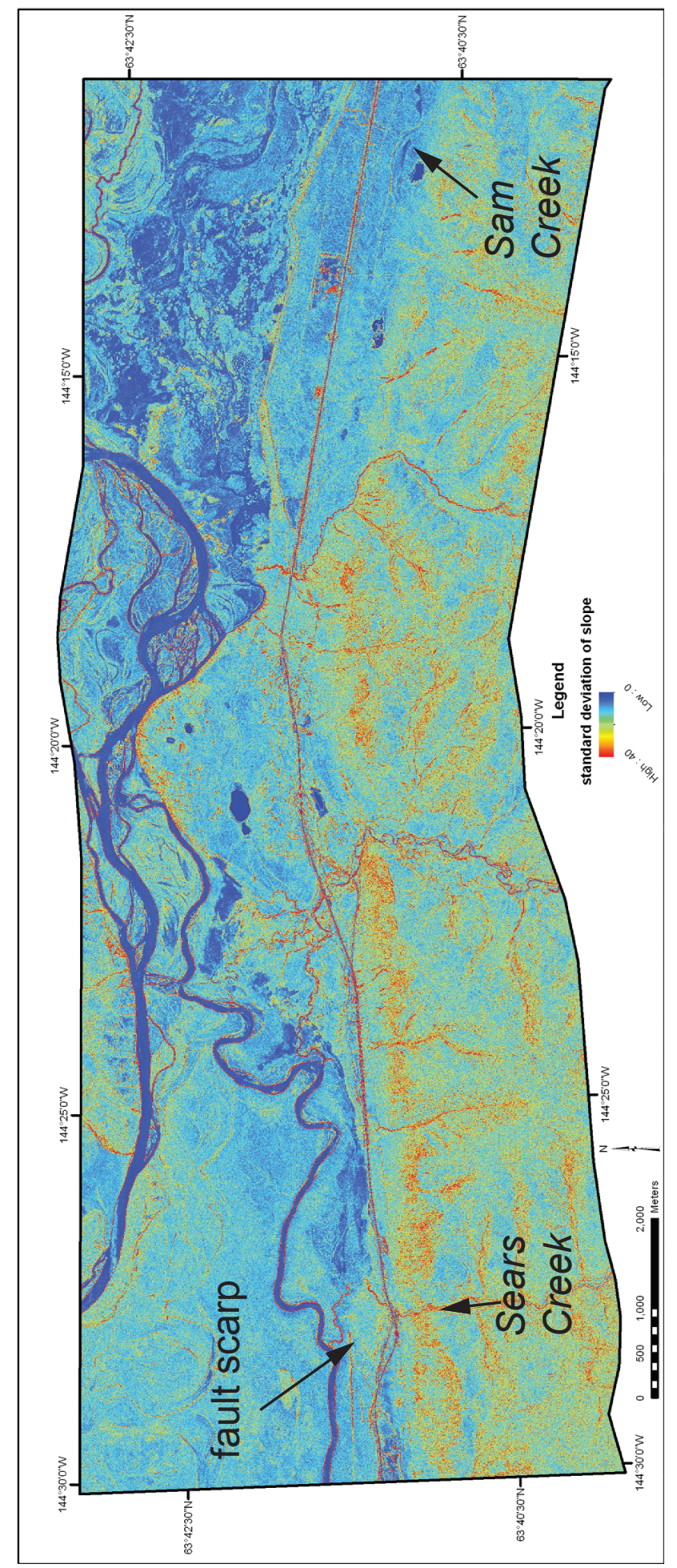

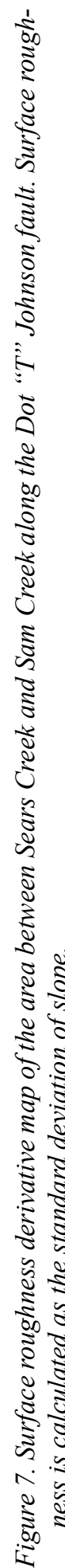




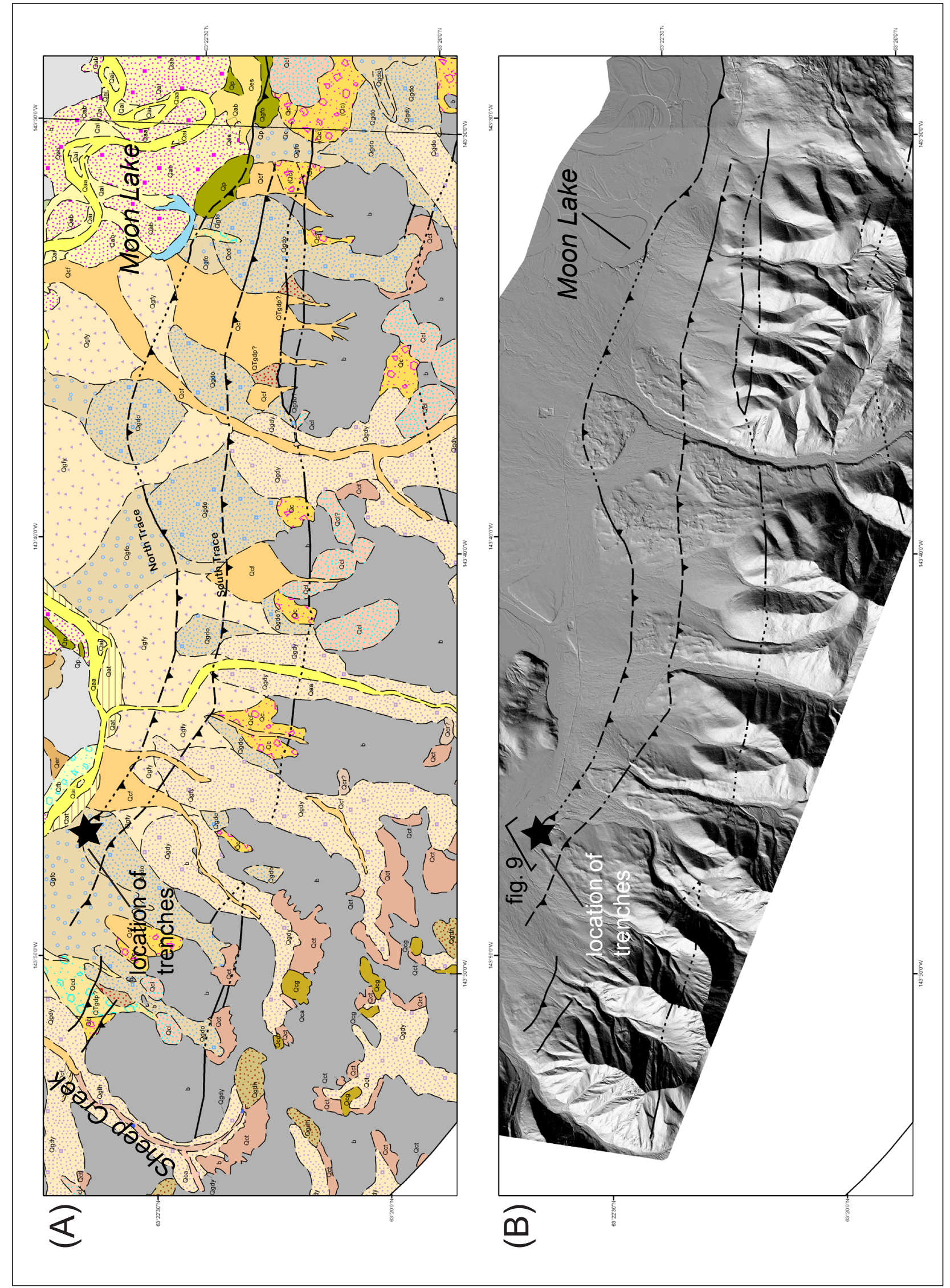

ปั่ ㅇ. 025

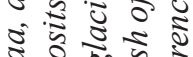
a) 200 نं

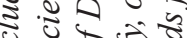
ช की 0 . 0

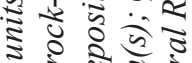

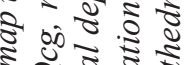
ㄴำ की 이 0 के

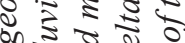

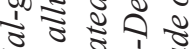
ชู ฐ - $5:$

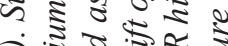
ฟ ปู

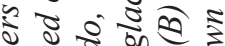

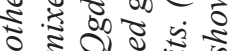

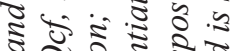

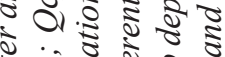

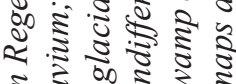
इ इ इ

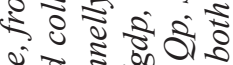

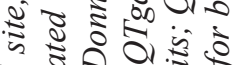
$-320 \overline{2}$

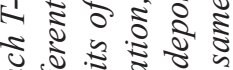

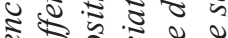
: 0 : 0 :

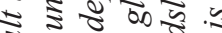

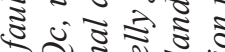
द 0.520

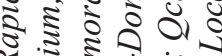

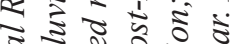

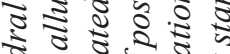

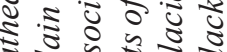
8 क 5 के - 00 ० 03

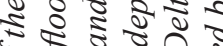
․

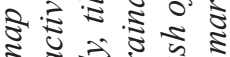
इ हैं डे दे

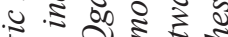
0.2 च च

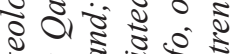
क्ष

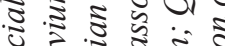
(⿻)丨

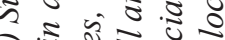
स.

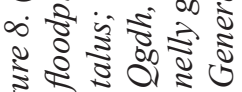
这 


\section{CATHEDRAL RAPIDS PALEOSEISMIC SITE}

Geologic mapping by Reger and others (2011) along the Cathedral Rapids fault in the vicinity of the Cathedral Rapids trench site indicates that the site geology consists of outwash (Qgfo) and till and associated morainal deposits (Qgdo) of the Delta glaciation (fig. 8A). Terraces and floodplain deposits of the Tanana River are present along the north side of the site and bury the glacial deposits. In the vicinity of the trench site, Quaternary uplift along the fault has resulted in well-developed triangular facets along the range front, indicating long-term progressive uplift (fig. 8B). The trench site is characterized by a steep bedrock range-front escarpment more than 30 $\mathrm{m}$ high and an oversteepened, $2.5-\mathrm{m}$-high scarp that obliquely projects away from the range front and cuts an outwash fan (figs. 8 and 9). Alluvial channels have convex profiles where they are incised through the scarp and have deposited Holocene alluvial fans at the scarp's base. Two trenches were excavated across the scarp by backhoe (trenches T-1 and T-2) and logged using standard paleoseismic methods including construction of a string grid and plotting measured points on graph paper at a scale of 1 inch: 1 meter.

\section{TRENCH STRATIGRAPHY}

Stratigraphic logs of the east and west walls of trench $\mathrm{T}-1$ are shown in figures 10 and 11 , respectively. The dominant unit exposed in the trench is a boulder-cobble diamicton (Unit 1), consisting of a coarser lower, bouldery unit and a finer upper, cobble unit. Both subunits are characterized by matrix-supported, subangular to subrounded boulders and cobbles of Alaska Range lithologies (gneiss and schist) up to $\sim 40 \mathrm{~cm}$ in diameter. Rare large clasts are weathered, suggesting that the unit was derived from nearby till of Delta age. Deformed sand bodies in the diamicton are consistent with dewatering of a debris flow derived from till upslope (D. Reger, oral commun., 2010), however an unknown amount of this deformation could be related to liquefaction. The diamicton layers are crudely bedded and imbricated, indicating transport to the north. The layers are generally parallel to the relatively flat surface south of the scarp and gradually change orientation, sloping parallel to the scarp face. The diamicton projects through the floor of the trench and was not encountered in a 1-m-deep test pit in the floor of the northern side of the trench.

The north end of the trench exposed a relatively younger alluvial package. The basal deposit (Unit 2) consists of interbedded, nonmicaceous, fine sand and clay layers that rest on the diamicton and dip $17-24^{\circ}$ to the north, parallel to the scarp face and the slope of the diamicton upslope. A prominent buried soil delineates the top of Unit 2 and represents a former ground surface and angular unconformity. The soil is overlain by flat-lying, interbedded, micaceous sands and silts (Unit 3) and alluvial gravels (Unit 4). Unit 4 is only exposed in the west wall of the trench and is interpreted to be sourced from the stream immediately west of the trench, which transported the gravels obliquely across the north end of the trench site (figs. 9 and 11). A thick loess and peat mat extends across the upper part of the exposure (Unit 5).

Trench T-2 showed nearly identical stratigraphic relations as exposed in $\mathrm{T}-1$. Heavy rains during our investigation resulted in partial trench collapse in the southern part of the trench and flooding. Figure 12 shows stratigraphic relations exposed in the footwall north of the topographic scarp. Similar to trench T-1, Unit 2 contains north-dipping beds of finely bedded silt, very fine sand, and clay layers. These sediments were emplaced in quiet water conditions and were likely deposited flat. A dark brown to black soil is developed in the top of Unit 2 and also dips to the north. Flat-lying bedded silt, fine sand, and gravel layers (Unit 3) bury the soil and Unit 2. The contact between Unit 2 and Unit 3 represents an angular unconformity. Unit 3 is buried by a $\sim 0.5$-m-thick package of loess.

No offset bedding, faults, or shears were observed in either trench. Abundant burned charcoal fragments are present in the younger alluvial package (Units 2, 3, and 4), as well as within the buried soil at the top of Unit 2. Radiometric analyses of four charcoal samples collected from the east wall of trench T-1 (table 1)indicate that Unit 2 was deposited during the late Holocene around 3,700 yr BP and that the buried soil (top of Unit 2) formed about 850 cal yr BP (fig. 10).

\section{INTERPRETATION AND ORIGIN OF THE SCARP}

Explanations for the origin of the scarp include: (1) an alluvial-fan-cut margin sourced from the stream valley to the east, (2) a flood scarp related to the Tanana River floodplain, or (3) deformation related to the $\mathrm{Ca}$ thedral Rapids fault. The stream valley to the east of the scarp is associated with a small, late Holocene alluvial fan that extends from the mouth of the canyon and does not bend to the west toward the trench site, discounting a fan-cut margin origin for the scarp (fig. 9).

Mica fragments in the upper sand deposit (Unit 3) suggest deposition by a flooding Tanana River. However, definitive evidence that the scarp was cut by fluvial events such as a cut bank in the diamicton (Unit 1) was not observed. Instead, the upper sand deposits (Unit 3) lap against the dipping lower sand and buried soil (Unit 2 ), suggesting that the scarp and inclined basal sand unit existed prior to burial along its base by Tanana River flood deposits. 


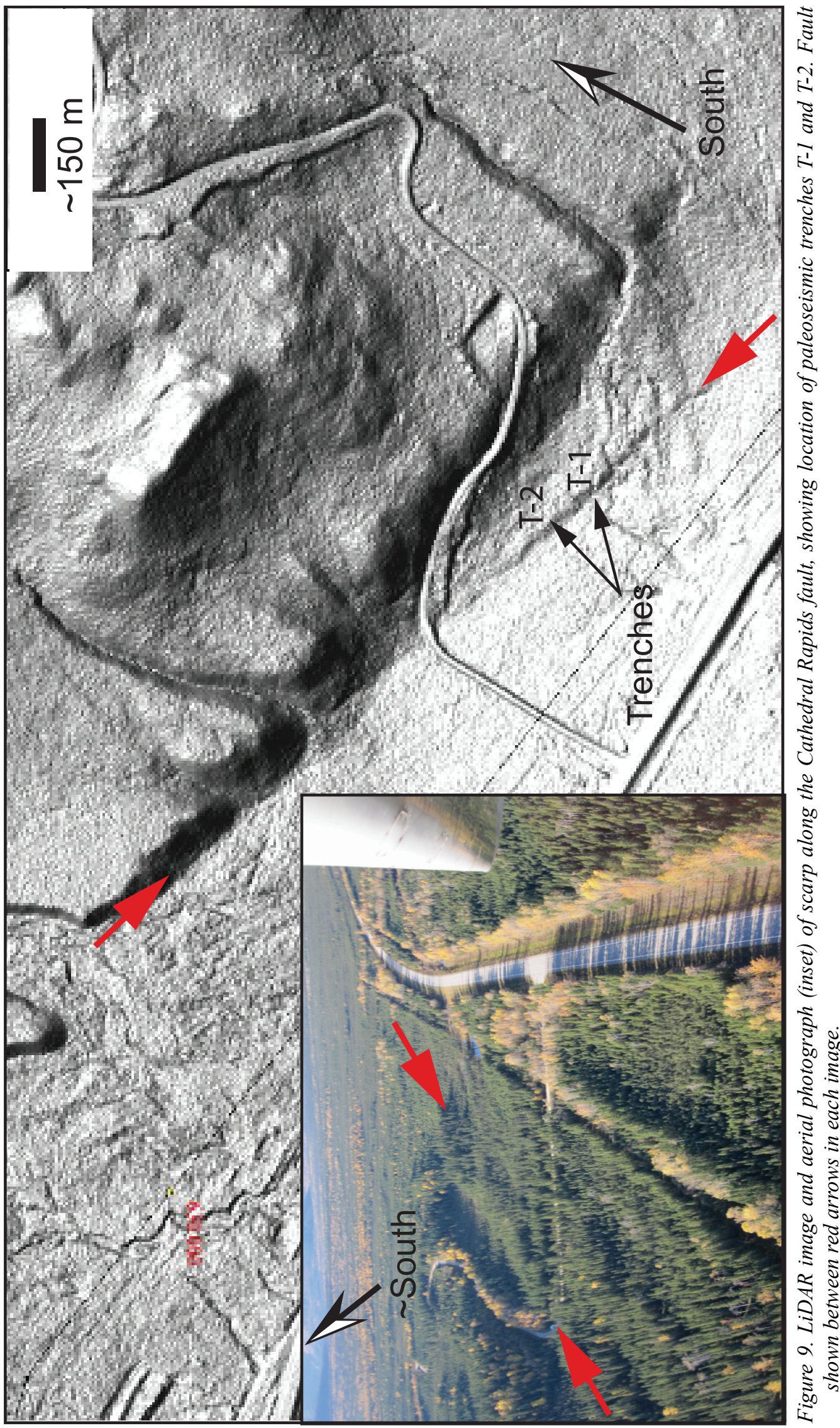




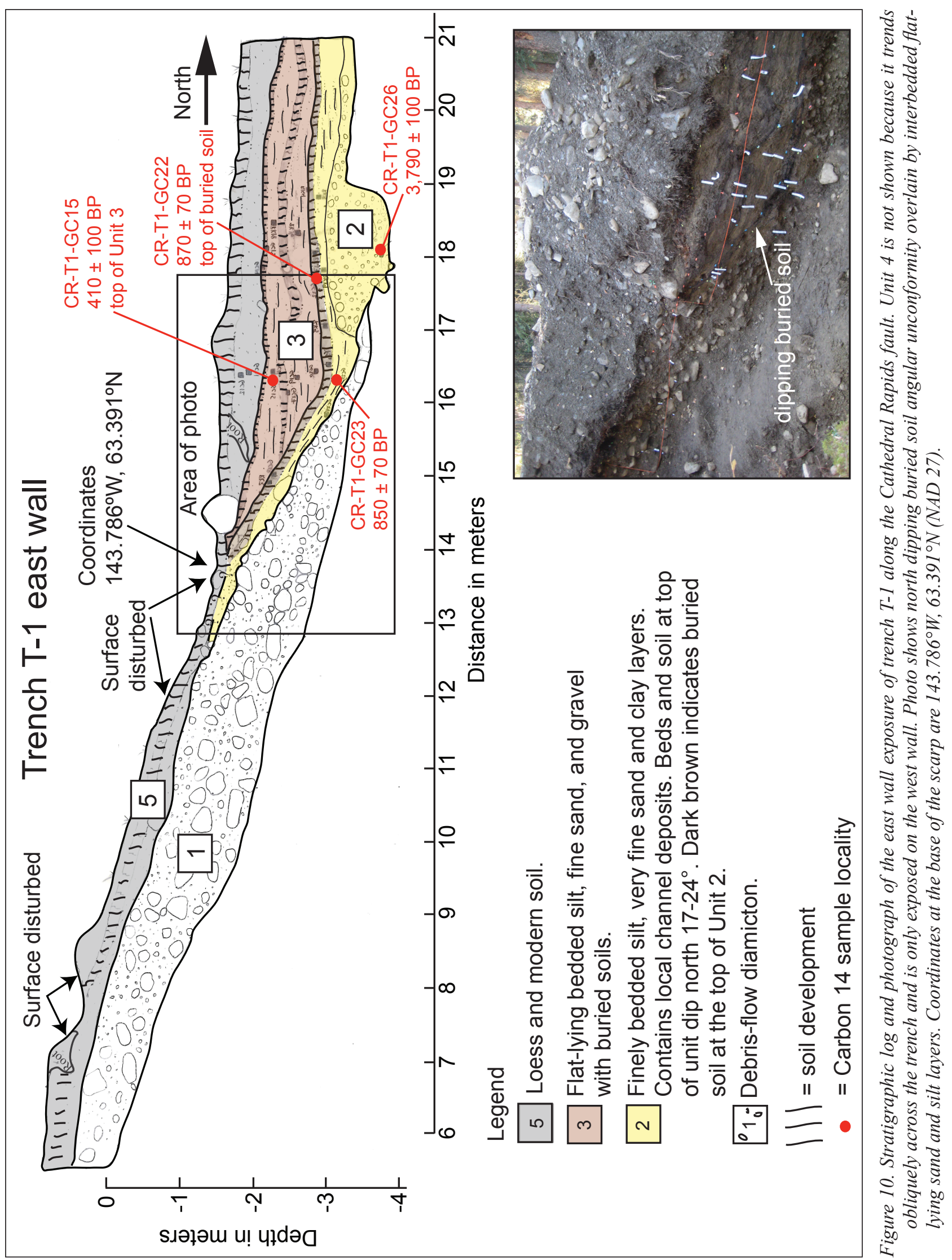




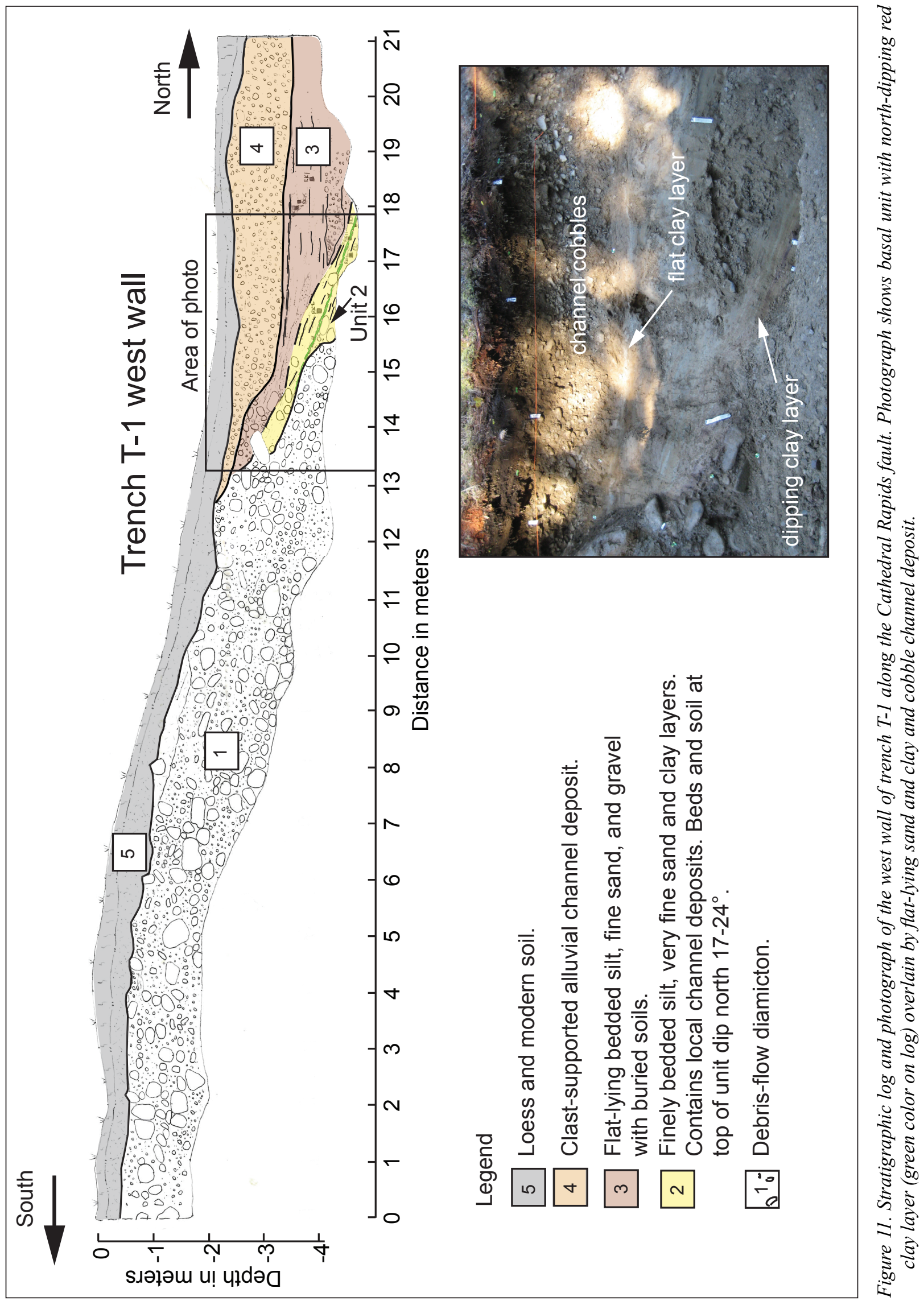


Table 1. Radiocarbon data from the Cathedral Rapids trenches. Location of samples shown on the trench log in figure 10. Radiocarbon analyses performed at Beta Analytic.

\begin{tabular}{|c|c|c|c|c|c|}
\hline $\begin{array}{c}\text { Radiocarbon } \\
\text { Sample }\end{array}$ & Location & $\begin{array}{c}\text { Lab } \\
\text { Number }\end{array}$ & ${ }^{14} \mathrm{C}$ Age BP ${ }^{*}$ & $\partial^{13} \mathrm{C} / \partial^{12} \mathrm{C}$ & $\begin{array}{c}\text { Cal yr BP } \\
\left(\text { (2бRange) }{ }^{\dagger}\right.\end{array}$ \\
\hline CR-T1-GC15 & $\mathrm{T}-1$, top Unit 3 & 292209 & $410 \pm 40$ & -27.3 & $410 \pm 100$ \\
\hline CR-T1-GC22 & T-1, top buried soil, Unit 2 & 292210 & $970 \pm 30$ & -25.1 & $870 \pm 70$ \\
\hline CR-T1-GC23 & $\mathrm{T}-1$, base buried soil, Unit 2 & 292211 & $930 \pm 30$ & -24.9 & $850 \pm 70$ \\
\hline CR-T1-GC26 & T-1, base Unit 2 & 292212 & $3,500 \pm 40$ & -24.2 & $3,790 \pm 100$ \\
\hline
\end{tabular}

\footnotetext{
${ }^{*}$ Using Libby half-life of 5,568 yr; relative to A.D. 1950.

$\dagger$ Calibrated ages calibrated with CALIB (version 5.0.1) and rounded to nearest decade (Stuiver and Reimer, 1993; Reimer and others, 2009).
}

The fine sand and clay layers in Unit 2 were deposited in a quiet water environment and likely laid down horizontally. These deposits now rest on the diamicton and dip $17-24^{\circ}$ to the north parallel to the scarp face and the slope of the diamicton (Unit 1). The diamicton contains imbricated cobbles that parallel the slope of the scarp. A subtle interbed in the diamicton contains large boulders up to $1 \mathrm{~m}$ in diameter. This interbed appears to be folded and projects through the floor of the trench. No clear fault plane was observed at the base of the scarp. Thus, based on these indirect observations and the proximity and alignment of the scarp with the north trace of the Cathedral Rapids fault, we infer that the scarp was formed by tilting or folding during one or more displacements along a blind thrust fault at depth. If this inference is correct, the stratigraphic relations suggest that the soil that caps Unit 2 was warped upward during a folding event prior to burial by Tanana River flood deposits. The radiocarbon results suggest that the earthquake occurred after the soil developed around 850 cal yr BP (table 1 and fig. 10).

\section{DISCUSSION AND POSSIBLE ANALOGUES}

The interpretation that the scarp is the result of tilting or folding above a blind thrust fault at depth is consistent with well documented studies of blind thrust-fault scarps created during the $1980 \mathrm{M}_{\mathrm{S}}=7.3 \mathrm{El}$ Asnam, Algeria (Meghraoui and others, 1988) and the $1999 \mathrm{M}_{\mathrm{w}}=7.6$ Chi-Chi, Taiwan (Kelson and others, 2001) earthquakes, as well as during a paleoearthquake along the Seattle fault in Washington (Nelson and others, 2003). These possible analogues are shown in figure 13. In Algeria, alluvial gravels were warped above a thrust tip, and a syncline developed on the footwall (fig. 13A). Younger, finer-grained sediments were deposited against the scarp in a similar manner to that observed in the Cathedral Rapids trench. In Taiwan, the folding was observed in areas of thick cobbles deposited by monsoons that acted to absorb the rupture. For example, at the Guangfu junior high school running track, the fold scarp developed above $>20 \mathrm{~m}$ of monsoon cobbles (fig. 13B). These deposits are similar to the debris flow fan deposits at the Cathedral Rapids trench site and may have contributed to the rounded crest and gentle slope morphology of the scarp at both sites. Finally, along the Seattle fault on Bainbridge Island, WA, Nelson and others (2003) documented a trench exposure that showed clearly folded late Holocene lake muds warped across a fault scarp (fig. 13C). No fault was identified in the trench, from which it was inferred that the fault was blind. Additional mapping and trenching along the scarp exposed clear faults and showed that the surface expression of the most recent earthquake transitioned along strike from surface folding to surface fault rupture over a distance of less than $100 \mathrm{~m}$ (Nelson and others, 2003).

The examples described above illustrate that fold scarps are common features along blind thrust faults and lend support to the proposed origin of the fold scarp at the Cathedral Rapids trench site. Additional trenching along the Cathedral Rapids fault is necessary to confirm a tectonic origin for the scarp. However, based on previous paleoseismic studies to the east and west of the site documenting multiple latest Pleistocene and Holocene earthquakes and the indirect stratigraphic evidence of blind thrust faulting documented in trench T-1, we infer that the most likely origin for the Cathedral Rapids scarp at the T-1 site is tectonic. This mechanism for scarp formation is consistent with multiple examples of tectonic surface folding during historic earthquakes elsewhere. 


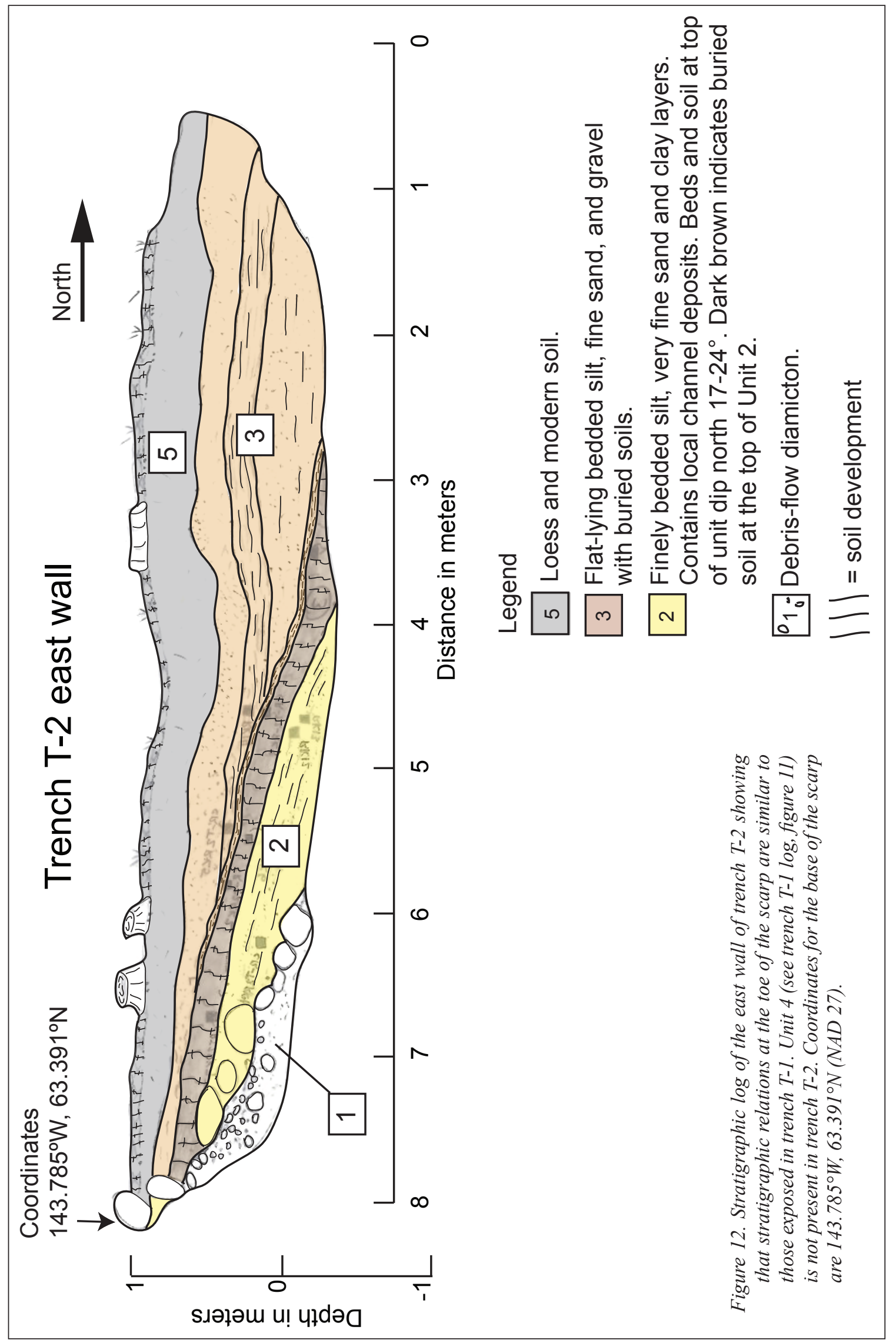




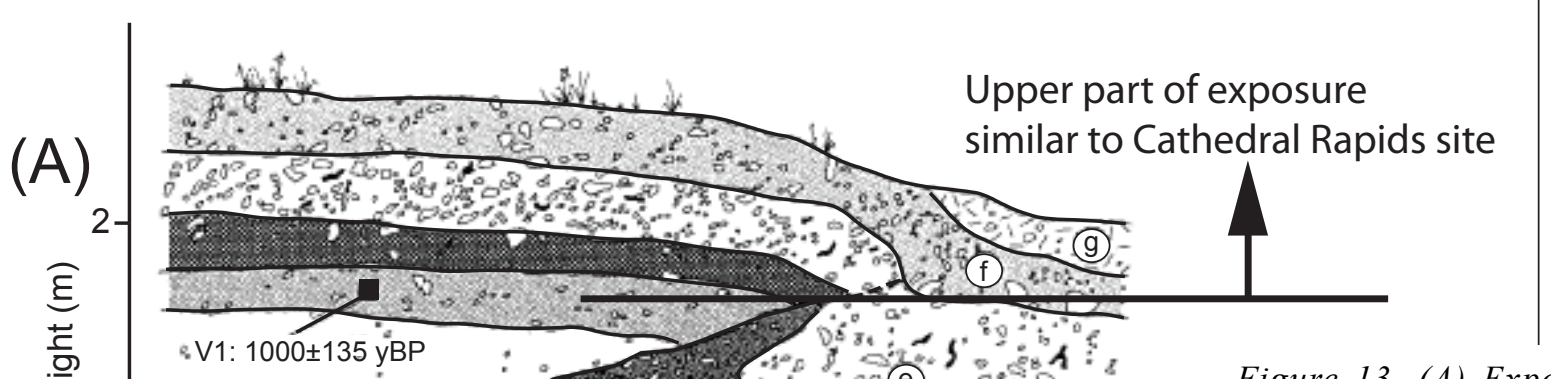

Figure 13. (A) Exposure of the 1980 Algeria rupture, showing blind thrust fault and associated folding (Meghraoui and others, 1988). Upper part of the exposure shows stratigraphic relations and folding similar to those seen in Cathedral Rapids trench T-1. (B) Folding at the Guangfu junior

(B)

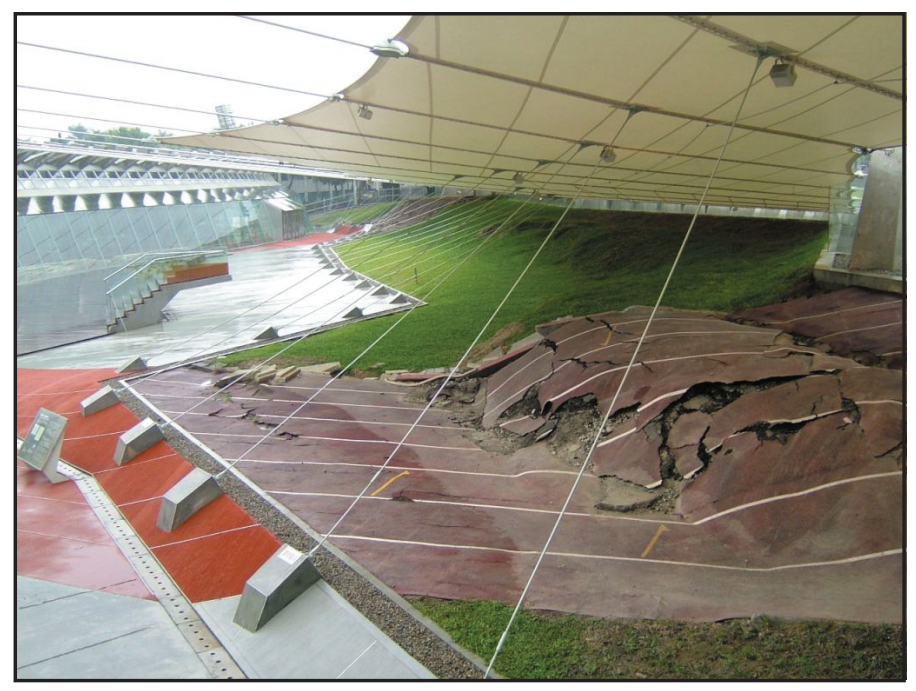
high school in Taiwan that occurred during the 1999 Chi-Chi earthquake along the Chelungpu fault. Image is from the 921 Earthquake Museum of Taiwan and shows the damaged running track now preserved at the museum. (C) Trench log from the Seattle fault, showing folding of Holocene lake mud across a topographic scarp (Nelson and others, 2003). The folding was inferred to be related to a blind thrust fault based on thrust faults observed in adjacent trenches. Red numbers are radiocarbon ages.

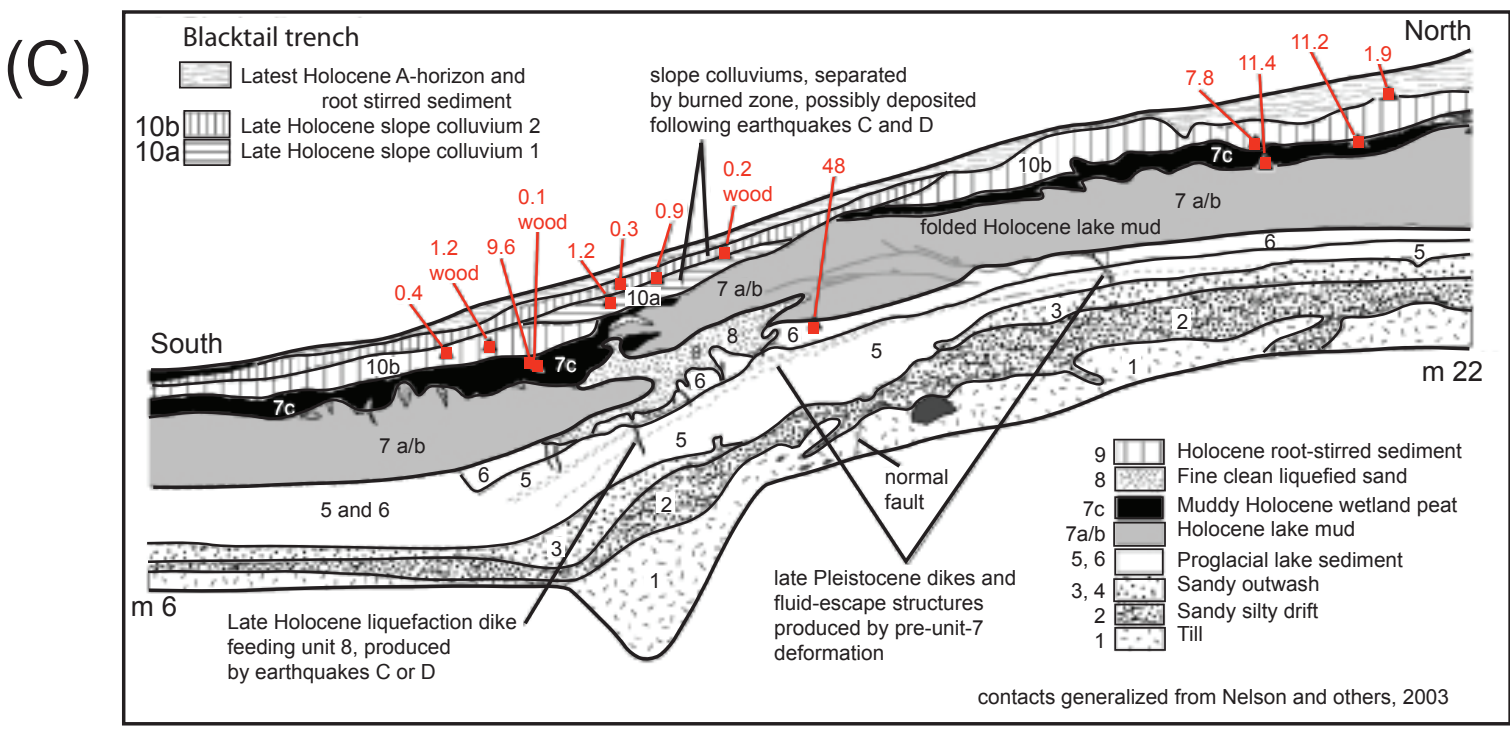




\section{CONCLUSIONS}

A variety of map products are now easily produced using ArcGIS and LiDAR data, including bare earth, slope, aspect, intensity, and surface roughness maps. Analyses using these derivative map products, including generation of detailed contour and hillshade maps, and evaluation of topography, are valuable tools in mapping Quaternary deposits and assessing geologic hazards. These relatively new techniques have important implications for hazard assessment and have become the industry standard for pipeline route selection and refinement, design, and construction (Hengesh and Lettis, 2005), as well as neotectonic research in Alaska and around the world (Schwartz and others, 2012; Koehler and others, 2012a,b; Oskin and others, 2007; 2012; Arrowsmith and Zielke, 2009; Zielke and others, 2012; Zielke and Arrowsmith, 2012).

The Cathedral Rapids fault is the easternmost recognized fault of the Northern Foothills Fold and Thrust Belt, yet has not been described southeast of the Tok River valley. New preliminary paleoseismic trench results suggest the occurrence of at least one folding event along the fault after around $850 \mathrm{cal} \mathrm{yr} \mathrm{BP}$. This result is consistent with well documented late Holocene earthquakes along the Dot " $T$ " Johnson and Cathedral Rapids faults west and east of the trench, respectively (Carver and others, 2010; 2008). It is possible that additional trenching along the fault may reveal the fault tip and lend further support to the tectonic origin for the scarp.

The Cathedral Rapids fault plays an active role in accommodating regional shortening across the Alaska Range and should be considered an active structure in seismic hazard assessments. Additional studies are necessary to better characterize parameters needed for seismic hazard assessment, including slip rate, slip per event, and recurrence interval.

\section{ACKNOWLEDGMENTS}

I thank Gary Carver, who originally showed me the scarps along the Dot "T" Johnson fault in the field and openly discussed his trench results. Assistance with the Cathedral Rapids fault trench by the TransCanada, Inc., fault evaluation team including Gary Carver, Jim McCalpin, Diana Solie, and Lili Weldon is greatly appreciated. A field review of the trench study by Dick Reger of Reger's Geologic Consulting; Rod Combellick, DeAnne Stevens, Gabriel Wolken, and Trent Hubbard of DGGS; and Mark Meyers and Eric Hatleberg of the Alaska Gasline Development Corporation provided valuable feedback. Reviews by Patty A.C. Burns and Marwan A. Wartes are appreciated, and helped improve the paper. Jim Weakland of DGGS provided GIS support for the generation of the LiDAR derivative maps. Additional thanks to Trent Hubbard (DGGS) and Dick
Reger for planning the 2012 Friends of the Pleistocene field trip where this material was originally presented and debated. And an extra thanks to Kenny Woods of DGGS, who furiously shoveled debris off the trench exposure-voluntarily!

\section{REFERENCES}

Arrowsmith, J.R., and Zielke, Olaf, 2009, Tectonic geomorphology of the San Andreas fault zone from high resolution topography-An example from the Cholame segment: Geomorphology, v. 113, p. 70-81.

Bemis, S.P., 2004, Neotectonic framework of the northcentral Alaska Range foothills: Fairbanks, Alaska, University of Alaska Fairbanks unpublished M.S. thesis, $142 \mathrm{p}$.

-2010, Moletrack scarps to mountains - Quaternary tectonics of the central Alaska Range: Eugene, Oregon, University of Oregon, Ph.D. dissertation, $121 \mathrm{p}$.

Bemis, S.P., and Wallace, W.K., 2007, Neotectonic framework of the north-central Alaska Range foothills, in Ridgway, K.D., Trop, J.M., Glen, M.G., and O’Neill, J.M., eds., Tectonic growth of a collisional continental margin-Crustal evolution of southern Alaska: Geological Society of America Special Paper 431, p. 549-572.

Bemis, S.P., Carver, G.A., and Koehler, R.D., 2012, The Quaternary thrust system of the northern Alaska Range: Geosphere, v. 8, no. 1, p. 1-10; doi:10.1130/ GES00695.1.

Biggs, Juliet, Wright, Tim, Lu, Zhong, and Parsons, Barry, 2007, Multi-interferogram method for measuring interseismic deformation-Denali fault, Alaska: Geophysical Journal International, v. 170, p. $1,165-1,179$.

Brogan, G.E., Cluff, L.S., Korringa, M.K., and Slemmons, D.B., 1975, Active faults of Alaska: Tectonophysics, v. 29, no. 1-4, p. 73-85.

Carver, G.A., Bemis, S.P., Solie, D.N., Castonguay, S.R., and Obermiller, K.E., 2010, Active and potentially active faults in or near the Alaska Highway corridor, Dot Lake to Tetlin Junction, Alaska: Alaska Division of Geological \& Geophysical Surveys Preliminary Interpretive Report 2010-1, 42 p.

Carver, G.A., Bemis S.P., Solie, D.N., and Obermiller, K.E., 2008, Active and potentially active faults in or near the Alaska Highway corridor, Delta Junction to Dot Lake, Alaska: Alaska Division of Geological \& Geophysical Surveys Preliminary Investigative Report 2008-3d, 32 p.

Eberhart-Phillips, Donna, Haeussler, P.J., Freymueller, J.T., Frankel, A.D., Rubin, C.M., Craw, Patricia A., Ratchkovski, N.A., Anderson, Greg, Carver, 
G.A., Crone, A.J., Dawson, T .E., Fletcher, Hilary, Hansen, Roger, Harp, E.L., Harris, R.A., Hill, D.P., Hreinsdottir, Sigrun, Jibson, R.W., Jones, L.M., Kayen, R.E., Keefer, D.K., Larsen, C.F., Moran, S.C., Personius, S.F., Plafker, George, Sherrod, B.L., Sieh, Kerry, Sitar, Nicholas, and Wallace, W.K., 2003, The 2002 Denali fault earthquake, Alaska-A large magnitude, slip-partitioned event: Science, v. 300, p. 1,113-1,118.

Fletcher, H.J., 2002, Crustal deformation in Alaska measured using the Global Positioning System: Fairbanks, Alaska, University of Alaska Fairbanks Ph.D. thesis, 135 p.

Frankel, K.L., and Dolan, J.F., 2007, Characterizing arid region alluvial fan surface roughness with airborne laser swath mapping digital topographic data: Journal of Geophysical Research, v. 112, no. F2, p. 25, doi:10.1029/2006JF000644.

Freymueller, J.T., Woodard, H., Cohen, S.C., Cross, R., Elliott, J., Larsen, C.F., Hreinsdottir, S., and Zweck, C., 2008, Active deformation processes in Alaska, based on 15 years of GPS measurements, in Freymueller, J.T., Haeussler, P.J., Wesson, R.L., and Ekstrom, G., eds., Active tectonics and seismic potential of Alaska: American Geophysical Union, Geophysical Monograph 179, p. 83-108.

Geomatrix Consultants, 1997, Final report-Site-specific earthquake ground motion study for radar building site, Clear Air Force Station, Alaska: Huntsville, AL, U.S. Army Engineering and Support Center, project number 3993.

Haeussler, P.J., 2008, An overview of the neotectonics of Interior Alaska-Far-field deformation from the Yakutat Microplate collision, in Freymueller, J.T., Haeussler, P.J., Wesson, R.L., and Ekstrom, G., eds., Active tectonics and seismic potential of Alaska: American Geophysical Union, Geophysical Monograph 179, p. 83-108.

Haeussler, P.J., Schwartz, D.P., Dawson, T.E., Stenner, H.D., Lienkaemper, J.J., Sherrod, B., Cinti, F.R., Montone, P., Craw, P.A., Crone, A.J., and Personius, S.F., 2004, Surface rupture and slip distribution of the Denali and Totschunda faults in the 3 November 2002 M 7.9 earthquake, Alaska: Bulletin of the Seismological Society of America, v. 94, no. 6B, p. S23-S52.

Hengesh, J.V., and Lettis, W.R., 2005, Active tectonic environments and seismic hazards, in Fookes, P.G., Lee, E.M., and Milligan, G., eds., Geomorphology for Engineers, 2nd edition: U.K., Whitties Publishing, p. 220-263, ISBN/ISSN: 978-1870325-03-5.

Hubbard, T.D., Koehler, R.D., and Combellick, R.A., 2011, High-resolution LiDAR data for Alaska infrastructure corridors, in DGGS Staff, LiDAR
Datasets of Alaska: Alaska Division of Geological \& Geophysical Surveys Raw Data File 2011-3A.

Hubbard, T.D., and Reger, R.D., 2010, Evidence for late Wisconsinan outburst floods in the Tok-Tanacross basin, upper Tanana River valley, east-central Alaska: Alaska Division of Geological \& Geophysical Surveys Newsletter 2010-1, 9 p.

Kelson, K.I., Kang, K.H., Page, W.D., Lee, C.T., and Cluff, L.S., 2001, Representative styles of deformation along the Chelungpu fault for the 1999 Chi-Chi (Taiwan) earthquake-Geomorphic characteristics and responses of man-made structures: Seismological Society of America Bulletin, v. 91, no. 5, p. 930-952.

Koehler, R.D., Farrell, Rebecca-Ellen, Burns, P.A.C., and Combellick, R.A., 2012a, Quaternary faults and folds in Alaska-A digital database, in Koehler, R.D., Quaternary Faults and Folds (QFF): Alaska Division of Geological \& Geophysical Surveys Miscellaneous Publication 141, 31 p., 1 sheet, scale 1:3,700,000.

Koehler, R.D., Reger, R.D., and Frohman, R.A., 2012b, The Castle Mountain fault, south-central AlaskaNew LiDAR-based observations on the sense of slip [poster]: Eos Transactions, American Geophysical Union, Fall Meeting Supplement, Abstract \#S53D2530. Posted on website of Alaska Division of Geological \& Geophysical Surveys, Posters and Presentations, 1 p., 1 sheet, http://dggs.alaska.gov/ pubs/id/24724.

Matmon, A., Schwartz, D.P., Haeussler, P.J., Finkel, R., Lienkaemper, J.J., Stenner, H.D., and Dawson, T.E., 2006, Denali fault slip rates and Holocene-late Pleistocene kinematics of central Alaska: Geology, v. 34, p. 645-648.

Meghraoui, M., Philip, H., Albarede, F., and Cisternas, A., 1988, Trench investigations through the trace of the 1980 El Asnam thrust fault_-Evidence for paleoseismicity: Bulletin of the Seismological Society of America, v. 78, no. 2, p. 979-999.

Meriaux, A.S., Sieh, Kerry, Finkel, R.C., Rubin, C.M., Taylor, M.H., Meltzner, A.J., and Ryerson, F.J., 2009, Kinematic behavior of southern Alaska constrained by westward decreasing postglacial slip rates on the Denali fault, Alaska: Journal of Geophysical Research, v. 114, no. B03, p. 404.

Nelson, A.R., Johnson, S.Y., Kelsey, H.M., Wells, R.E., Sherrod, B.L., Pezzopane, S.K., Bradley, L., Koehler, R.D., and Bucknam, R.C., 2003, Late Holocene earthquakes on the Toe Jam fault, Seattle fault zone, Bainbridge Island, Washington: Geological Society of America Bulletin, v. 122, no. 9/10, p. 1,388-1,403.

Oskin, M.E., Arrowsmith, J.R., Hinojosa Corona, A., Elliott, A.J., Fletcher, J.M., Fielding, E.J., Gold, P.O. Gonzalez Garcia, J., Hudnut, K.W., Liu-Zeng, J., and 
Teran, O.J., 2012, Near-field deformation from the El Mayor-Cucapah earthquake revealed by differential LIDAR: Science, v. 335, no. 6069, p. 702-705.

Oskin, M.E., Le, Kimberley, and Strane, M.D., 2007, Quantifying fault-zone activity in arid environments with high-resolution topography: Geophysical Research Letters, v. 34, no. 23, 1 p.

Péwé, T.L., Wahrhaftig, Clyde, and Weber, F.R., 1966, Geologic map of the Fairbanks quadrangle, Alaska: U.S. Geological Survey Miscellaneous Geological Investigations Map I-455, 1 sheet, scale 1:250,000.

Reger, R.D., Hubbard, T.D., and Gallagher, P.E., 2012, Surficial geology of the Alaska Highway corridor, Tetlin Junction to Canada border, Alaska: Alaska Division of Geological \& Geophysical Surveys Preliminary Interpretive Report 2012-1A, 25 p., 2 sheets, scale 1:63,360.

Reger, R.D., Hubbard, T.D., and Carver, G.A., 2011, Surficial geology of the Alaska Highway corridor, Robertson River to Tetlin Junction, Alaska: Alaska Division of Geological \& Geophysical Surveys Preliminary Interpretive Report 2009-6a, 53 p., 4 sheets, scale 1:63,000.

Reger, R.D., Stevens, D.S.P., and Solie, D.N., 2008a, Evidence of multiple outburst floods, upper Tanana River valley, east-central Alaska [abs.]: Geological Society of America Abstracts with Programs, v. 40, no. 1 , p. 36 .

-2008b, Surficial-geologic map of the Alaska Highway corridor, Delta Junction to Dot Lake, Alaska: Alaska Division of Geological \& Geophysical Surveys Preliminary Interpretive Report 2008-3a, 2 sheets, scale 1:63,360.

Reimer, P.J, Baillie, M.G.L., Bard, E., Bayliss, A., Beck, J.W., Blackwell, P.G., Ramsey, C. Bronk, Buck, C.E., Burr, G.S., Edwards, R.L., Friedrich, M., Grootes, P.M, Guilderson, T.P., Hajdas, I., Heaton, T.J., Hogg, A.G., Hughen, K.A., Kaiser, K.F., Kromer, B., McCormac, F.G., Manning, S.W., Reimer, R.W., Richards, D.A., Southon, J.R., Talamo, S., Turney, C.S.M., van der Plicht, J., and Weyhenmeyer, C.E., 2009, IntCal09 and Marine09 radiocarbon age calibration curves, 0-50,000 years cal BP: Radiocarbon, v. 51, no. 4, p. 1,111-1,150.

Ridgway, K.D., Thoms, E.E., Layer, P.W., Lesh, M.E., White, J.M., and Smith, S.V., 2007, Neogene transpressional foreland basin development on the north side of the central Alaska Range, Usibelli Group and Nenana Gravel, Tanana basin, in Ridgway, K.D., Trop, J.M. Glen, J.M.G., and O’Neill, Michael, eds., Tectonic Growth of a Collisional Continental Margin-Crustal Evolution of South- ern Alaska: Boulder, Colorado, Geological Society of America Special Paper, v. 431, p. 507-547, doi:10.1130/2007.2431(20).

Ruppert, N.A., Ridgway, K.D., Freymueller, J.T., Cross, R.S., and Hansen, R.A., 2008, Active tectonics of interior Alaska - Seismicity, GPS geodesy, and local geomorphology, in Freymueller, J.T., Haeussler, P.J., Wesson, R.L., and Ekstrom, G., eds., 2008, Active tectonics and seismic potential of Alaska: American Geophysical Union, Geophysical Monograph 179, p. 83-108.

Schmoll, H.R., 1984, Late Pleistocene morainal and glaciolacustrine geology in the upper Copper River-Mentasta Pass area, Alaska [abs.]: Geological Society of America Abstracts with Programs, v. 16, no. 6, p. 332.

Schwartz, D.P., Haeussler, P.J., Seitz, G.G., and Dawson, T.E., 2012, Why the 2002 Denali fault rupture propagated onto the Totschunda fault-Implications for fault branching and seismic hazards: Journal of Geophysical Research, v. 117, no. B11, p. 304.

St. Amand, Pierre, 1957, Geological and geophysical synthesis of the tectonics of portions of British Columbia, the Yukon Territory, and Alaska: Geological Society of America Bulletin, v. 68, no. 10, p. 1,343-1,370.

Stuiver, Minze, and Reimer, P.J., 1993, Extended ${ }^{14} \mathrm{C}$ database and revised CALIB $3.0{ }^{14} \mathrm{C}$ age calibration program: Radiocarbon, v. 35, no. 1, p. 215-230.

Thoms, E.E., 2000, Late Cenozoic unroofing sequence and foreland basin development of the central Alaska Range-Implications from the Nenana Gravel: Fairbanks, Alaska, University of Alaska M.S. thesis, $215 \mathrm{p}$.

Thorson, R.M., 1979, Recurrent late Quaternary faulting near Healy, Alaska, in Short Notes on Alaskan Geology, 1978: Alaska Division of Geological \& Geophysical Surveys Geologic Report 61, p. 10-14.

Wahrhaftig, Clyde, Wolfe J.A., Leopold, E.B., and Lanphere, M.A., 1969, The coal-bearing group in the Nenana coal field, Alaska: U.S. Geological Survey, Bulletin 1274-D, 30 p.

Zielke, Olaf, and Arrowsmith, J.R., 2012, LaDiCaoz and LiDAR imager-MATLAB GUIs for LiDAR data handling and lateral displacement measurement: Geosphere, v. 8, no. 1, p. 206-221.

Zielke, Olaf, Arrowsmith, J.R., Grant-Ludwig, L.B., and Akciz, S.O., 2012, High-resolution topographyderived offsets along the 1857 Fort Tejon earthquake rupture trace, San Andreas fault: Bulletin of the Seismological Society of America, v. 102, no. 3, p. 1,135-1,154. 